\title{
Pozycja Polski w zakresie prac badawczych i rozwojowych w Unii Europejskiej
}

\section{Pojęcie i znaczenie ekonomiczne prac badawczych i rozwojowych $(B+R)$}

Analiza pozycji Polski w zakresie B+R w UE wymaga na wstępie wyjaśnienia pojęcia tych prac. Prace badawcze obejmują badania podstawowe (basic research) i stosowane (applied research). Badania podstawowe są pracami o charakterze teoretycznym albo eksperymentalnym, zmierzającymi do odkrycia właściwości zjawisk i ogólnych między nimi zależności (Budziński, 1972, s. 10). Nie mają one zatem celu praktycznego. Badania te są prowadzone głównie w uczelniach wyższych, ale i w pewnej mierze w państwowych instytucjach naukowych i placówkach badawczych firm. Ich rezultat stanowią odkrycia naukowe, prezentowane w artykułach i książkach naukowych. Badania podstawowe występują we wszystkich dziedzinach nauki, a więc w zakresie nauk przyrodniczych, technicznych, społecznych i humanistycznych. Wyrażają się np. w określeniu sekwencji aminokwasów w cząsteczce przeciwciała (OECD, 2002, Podręcznik Frascati..., s. 92 i 93).

Badania stosowane mają - odmiennie niż badania podstawowe - cel praktyczny. Zmierzają do uzyskania rezultatów, które można byłoby wykorzystać w szczególności do opracowania nowych albo udoskonalonych produktów i procesów technologicznych. Badania stosowane realizuje się zwłaszcza w uczelniach wyższych i placówkach badawczych firm. Efektem tych badań jest najczęściej wynalazek i występują one w zakresie nauk przyrodniczych, technicznych, społecznych i humanistycznych. Są nimi m.in. analizy sekwencji aminokwasów prowadzone w celu rozróżnienia przeciwciał dla różnych chorób (OECD, 2002, Podręcznik Frascati..., s. 92 i 93).

Prace rozwojowe (development) stanowią ostatni etap działalności naukowej. Następuje tu systematyczne wykorzystanie wyników badań naukowych, a w konsekwencji uzyskanie zwłaszcza nowych albo udoskonalonych produktów i procesów technologicznych. Prace te są realizowane zasadniczo w dziedzinie nauk przyrodniczych, technicznych i społecznych, głównie w placówkach badawczych gospodarki. Prowadzą one ostatecznie do powstania innowacji. Przykładem takich aktywności jest opracowanie metody syntezy przeciwciał dla konkretnej choroby opartej na wiedzy o ich strukturze oraz na klinicznym testowaniu skuteczności syntetycznych przeciwciał na pacjentach (OECD, 2002, Podręcznik Frascati..., s. 92).

Od poziomu $\mathrm{B}+\mathrm{R}$ określonego państwa zależy w istotnej mierze jego wzrost gospodarczy. Prace badawcze i rozwojowe - ich skala i struktura są bowiem kluczowym czynnikiem wpływającym na postęp techniczny. Ostateczny efekt tych prac stanowią głównie innowacje procesów produkcyjnych i produktów. Pierwszy z wymienionych 
rodzajów innowacji, określany także jako postęp techniczny stosowany, polega na zastosowaniu nowych albo udoskonalonych procesów technologicznych. Innowacje produktów, czyli postęp techniczny wytwarzany, wyrażają się we wprowadzaniu do produkcji nowych albo udoskonalonych produktów. Konsekwencją dokonującego się w gospodarce postępu technicznego stosowanego jest wzrost wydajności lub spadek materiałochłonności produkcji. Następuje więc obniżenie kosztów produkcji, co stwarza przesłanki dla jej wzrostu na rynku krajowym czy na rynkach zagranicznych. Rozwój postępu technicznego wytwarzanego kreuje popyt na nowe albo udoskonalone produkty. Niejednokrotnie prowadzi do powstania nowych gałęzi gospodarki. Przykładowo wynalezienie komputera doprowadziło do powstania przemysłów techniki informacyjnej i telekomunikacyjnej. Pierwszy wytwarza m.in. sprzęt komputerowy i oprogramowanie, a drugi - sprzęt teleinformatyczny, instalacje teletechniczne i centrale telefoniczne. Są to obecnie przemysły o szczególnym znaczeniu dla wzrostu gospodarczego.

\section{Mierniki pozycji w dziedzinie $B+R$ i jej uwarunkowania}

Państwa Unii Europejskiej są krajami o zróżnicowanym potencjale ekonomicznym i ludnościowym. Stąd też w powyższym artykule analizuje się relatywną pozycję Polski w zakresie $\mathrm{B}+\mathrm{R}$ na tle innych krajów UE, tzn. uwzględniającą różnice $\mathrm{w}$ wielkości produktu krajowego brutto (PKB) lub ludności.

Dla określenia tej pozycji w dziedzinie $\mathrm{B}+\mathrm{R}$, można posłużyć się kilkoma wskaźnikami, a wśród nich liczbą publikacji naukowych przypadającą na 1 mln mieszkańców danego kraju. Publikacje powstają głównie w szkołach wyższych. Wskaźnik ten nie jest jednak pozbawiony pewnych wad, gdyż jego wzrost nie musi zawsze świadczyć o dokonującym się postępie naukowym.

Dalszy wskaźnik to liczba cytowań przypadających na jedną publikację naukową. W krajach o wyższym poziomie rozwoju nauki liczba ta jest większa, gdyż postęp naukowy nie następuje w próżni, ale w wyniku współdziałania wielu badaczy, wykorzystywania w swych pracach naukowych badań innych naukowców.

$\mathrm{W}$ dużym stopniu na dokonanie oceny jakości wyników prowadzonych $\mathrm{B}+\mathrm{R}$ pozwala zastosowanie jako wskaźnika liczby ważnych patentów na 1 mln ludności. Za szczególnie istotne uznaje się tzw. patenty triady, czyli zgłoszone łącznie w trzech najważniejszych (w skali międzynarodowej) urzędach patentowych, a mianowicie w Europejskim Urzędzie Patentowym (the European Patent Office - EPO), Japońskim Urzędzie Patentowym (the Japanese Patent Office - JPO) oraz Amerykańskim Urzędzie Patentowym (US Patent \& Trademark Office - USPTO).

Ważnymi patentami są również uzyskane stosownie do zasad traktatu PCT (Patent Cooperation Treaty). Procedura związana z tym traktatem pozwala na dążenie do otrzymania praw patentowych w większej liczbie krajów poprzez wypełnienie pojedynczego (międzynarodowego) wniosku w jednym urzędzie patentowym, a następnie wstapienie na płaszczyznę narodową w pożądanym kraju.

O ochronę rezultatów swych prac naukowych wnioskują zwłaszcza przedsiębiorstwa. Chcą tym samym przeciwdziałać (nieodpłatnemu) dostępowi do tych rezultatów 
podmiotów trzecich, a więc negatywnym efektom zewnętrznym $\mathrm{B}+\mathrm{R}$ (external effects). Efekty zewnętrzne mogą nastąpić np. na skutek imitacji.

Relatywna pozycja danego kraju w dziedzinie prac badawczych i rozwojowych zależy od wielu czynników. Warto tu zwrócić uwagę na kilka z nich, w tym na intensywność badawczo-rozwojową. Rozumie się przez nią udział ogólnych krajowych wydatków na B+R (,Gross Domestic Expenditiure on R+D” - GERD) w produkcie krajowym brutto (PKB) analizowanego kraju, wyrażony w procentach.

Kolejnym czynnikiem jest struktura źródeł finansowania B+R. Najbardziej korzystnym jest prymat gospodarki w ponoszeniu kosztów tych prac. Ze zrozumiałych względów przedsiębiorstwa są zainteresowane $\mathrm{w}$ finansowaniu $\mathrm{B}+\mathrm{R}$, których wyniki znajdują praktyczne zastosowanie w procesie produkcji. Taki charakter mają badania stosowane i prace rozwojowe. Są to jednocześnie aktywności najbardziej kosztowne. Firmy orientują się lepiej niż państwo, jakie tego rodzaju prace podejmować, gdyż szybciej reagują na impulsy pochodzące z rynku.

Funkcja państwa winna polegać na popieraniu w szczególności badań podstawowych, co znajduje teoretyczne uzasadnienie w charakterze wiedzy naukowej, powstającej w wyniku prac naukowych. Ma ona w określonej mierze charakter tzw. dóbr publicznych. Są to dobra, z których korzystania nikt nie może być wyłączony i które mogą być „konsumowane” w tym samym czasie przez różne podmioty. Dobra publiczne byłyby produkowane w zbyt wąskim zakresie, gdyby ich wytwarzanie było finansowane jedynie przez przedsiębiorstwa (Öffentliches Gut; Cowen; Klodt, 1995, s. 109). Wśród rezultatów $\mathrm{B}+\mathrm{R}$ charakter dóbr publicznych mają wyniki badań podstawowych. Koszty tych badań powinno zatem w największym stopniu ponosić państwo. Jego interwencję uzasadnia się także potrzebą uzyskania pozytywnych efektów zewnętrznych badań. W przypadku finansowania badań podstawowych wyłącznie przez szkoły wyższe i firmy podmioty te nie byłyby zainteresowane w bezpłatnej dyfuzji uzyskanej wiedzy naukowej. Może zapewnić ją jedynie państwo.

Sama znaczna intensywność badawczo-rozwojowa oraz kluczowa rola gospodarki $\mathrm{w}$ finansowaniu $\mathrm{B}+\mathrm{R}$ nie wystarczają jednak, aby zapewnić wysoki poziom nauki $\mathrm{w}$ danym kraju. Niezbędne jest popieranie prac badawczych i rozwojowych zwłaszcza przez branże gospodarki wytwarzające dobra o wysokim albo średnio-wysokim zaawansowaniu technologicznym. Konsekwencją takiej struktury finansowania B+R jest koncentracja prac naukowych w przemyśle i położenie nacisku na tworzenie nowoczesnych albo bardzo nowoczesnych produktów i technologii. Ważne jest również zapewnienie odpowiedniej współpracy pomiędzy poszczególnymi sektorami instytucjonalnymi nauki i w ramach tych sektorów, a zwłaszcza między uczelniami wyższymi i firmami. W szkołach wyższych realizowana jest znaczna część badań podstawowych i stosowanych. Podjęcie współdziałania pozwala firmom na ukierunkowanie badań uczelnianych zgodnie z sygnałami płynącymi z rynku.

Istotne jest także rozwinięcie szeroko zakrojonego współdziałania w zakresie prac badawczych i rozwojowych z zagranicą. Ma ono dużą wagę zwłaszcza w przypadku mniejszych krajów lub wykazujących określony niedorozwój w dziedzinie nauki. 


\section{Ocena pozycji Polski w zakresie B+R w Unii}

W starych państwach członkowskich powstawało w badanym okresie znacznie więcej publikacji naukowych na $1 \mathrm{mln}$ mieszkańców niż w Polsce (patrz tabela 1). Największą przewagę wykazywały przy tym Szwecja, Dania Finlandia i Holandia. Wskaźnik ten był tam odpowiednio o średnio 308,0\%, 292,9\%, 273,5\% i 251,8\% wyższy. Również w większości nowych krajów członkowskich UE produkcja publikacji naukowych na 1 mln mieszkańców była wyższa niż w Polsce (patrz tabela 1). W przypadku Słowenii, Cypru, Estonii, Czech, Słowacji i Wegier dotyczyło to całego okresu 2004-2011.

W starych państwach członkowskich liczba cytowań przypadających na 1 publikację naukową była dużo wyższa niż w Polsce (patrz tabela 1). Najwyższa (średnia) liczba tych cytowań występowała w Danii $(15,73)$, Holandii $(15,13)$, Szwecji $(14,11)$ i Belgii $(13,51)$, podczas gdy w Polsce wynosiła ona jedynie 6,17. Również większość nowych państw członkowskich notowała wyższy wskaźnik, przy czym wyróżniały się Estonia $(10,80)$, Węgry $(9,00)$, Malta $(8,44)$ i Cypr $(8,10)$.

Także pod względem liczby patentów na 1 mln mieszkańców stare państwa członkowskie wyprzedzały Polskę (patrz tabela 1). W dziedzinie patentów triady największa była przewaga Szwecji, Niemiec, Finlandii i Holandii. Zgłaszały one odpowiednio około 77,8, 63,0, 54,4 i 53,0 patentu, a Polska jedynie - 0,2. Z kolei w zakresie patentów dotyczących technologii informacyjnej i telekomunikacyjnej wyróżniały się wśród starych państw członkowskich Finlandia, Szwecja, Holandia i RFN, na które przypadało odpowiednio około $151,2,110,3,76,7$ i 48,9 patentu. Wskaźnik ten wynosił w przypadku Polski średnio 1,0. Starymi krajami członkowskimi o największej (średniej) liczbie patentów poświęconych biotechnologii na 1 mln mieszkańców były Dania (32,2 patentu), Holandia (14,3 patentu), Szwecja (13,6 patentu) i Belgia (11,9 patentu). Tymczasem z Polski pochodziło jedynie 0,4 patentu.

Wśród analizowanych nowych państw członkowskich Polska ustępowała pod względem wskaźników dotyczących patentów przeważnie Czechom, Estonii, Słowacji, Słowenii i Węgrom (patrz tabela 1). Na podstawie dotychczasowych rozważań można sformułować wniosek, że Polska była w Unii Europejskiej krajem o bardzo słabej (relatywnej) pozycji w zakresie prac badawczych i rozwojowych.

Tabela 1

Publikacje naukowe, cytowania i patenty na 1 mln mieszkańców w krajach UE w latach 2004-2011

\begin{tabular}{||c|c|c|c|c|c|c||}
\hline Kraj & Rok & $\begin{array}{c}\text { Publikacje } \\
\text { naukowe } \\
\text { na 1 mln } \\
\text { mieszkańców }\end{array}$ & $\begin{array}{c}\text { Liczba cytowań } \\
\text { na 1 publikację }\end{array}$ & $\begin{array}{c}\text { Patenty triady } \\
\text { na 1 mln } \\
\text { mieszkańców }\end{array}$ & $\begin{array}{c}\text { Patenty } \\
\text { w sektorze ITC } \\
\text { na 1 mIn } \\
\text { mieszkańców }\end{array}$ & $\begin{array}{c}\text { Patenty w sek- } \\
\text { torze biotechno- } \\
\text { logii na 1 mln } \\
\text { mieszkańców b }\end{array}$ \\
\hline 1 & 2 & 3 & 4 & 5 & 6 & 7 \\
\hline Austria & 2004 & 1500 & 20,27 & 46,0 & 33,9 & 7,6 \\
& 2005 & 1647 & 17,89 & 51,3 & 37,9 & 6,7 \\
& 2006 & 1698 & 15,33 & 36,0 & 46,2 & 10,0 \\
& 2007 & 1817 & 13,74 & 34,4 & 45,1 & 9,2 \\
& 2008 & 1912 & 11,10 & 32,7 & 33,7 & 8,1 \\
& 2009 & 2036 & 8,53 & 35,0 & 31,4 & 9,4 \\
& 2010 & 2132 & 6,38 & 36,1 & 30,5 & $11,4^{\text {a }}$ \\
\hline
\end{tabular}




\begin{tabular}{|c|c|c|c|c|c|c|}
\hline 1 & 2 & 3 & 4 & 5 & 6 & 7 \\
\hline Belgia & $\begin{array}{l}2004 \\
2005 \\
2006 \\
2007 \\
2008 \\
2009 \\
2010 \\
2011 \\
\end{array}$ & $\begin{array}{l}1614 \\
1809 \\
1853 \\
1955 \\
2060 \\
2201 \\
2262 \\
2390 \\
\end{array}$ & $\begin{array}{r}21,67 \\
20,38 \\
17,40 \\
15,42 \\
13,20 \\
9,95 \\
6,62 \\
3,42 \\
\end{array}$ & $\begin{array}{l}39,6 \\
39,2 \\
30,4 \\
31,0 \\
30,0 \\
27,2 \\
28,0 \\
28,3 \\
\end{array}$ & $\begin{array}{l}19,7 \\
21,9 \\
20,0 \\
21,7 \\
21,2 \\
23,3 \\
25,0 \\
29,8^{\text {a }} \\
\end{array}$ & $\begin{array}{l}10,8 \\
10,9 \\
11,2 \\
13,7 \\
11,5 \\
11,9 \\
11,9 \\
13,5^{\text {a }}\end{array}$ \\
\hline Bułgaria & $\begin{array}{l}2004 \\
2005 \\
2006 \\
2007 \\
2008 \\
2009 \\
2010 \\
2011 \\
\end{array}$ & $\begin{array}{l}312 \\
362 \\
346 \\
439 \\
428 \\
472 \\
466 \\
469 \\
\end{array}$ & $\begin{array}{l}9,76 \\
7,89 \\
9,16 \\
6,56 \\
6,15 \\
4,42 \\
2,59 \\
1,80 \\
\end{array}$ & $\begin{array}{l}. \\
. \\
. \\
. \\
. \\
. \\
. \\
\end{array}$ & $\begin{array}{l}. \\
. \\
. \\
. \\
. \\
. \\
.\end{array}$ & $\begin{array}{l}. \\
\dot{.} \\
\dot{.} \\
. \\
. \\
.\end{array}$ \\
\hline Cypr & $\begin{array}{l}2004 \\
2005 \\
2006 \\
2007 \\
2008 \\
2009 \\
2010 \\
2011 \\
\end{array}$ & $\begin{array}{r}590 \\
753 \\
775 \\
905 \\
1080 \\
1482 \\
1674 \\
1709 \\
\end{array}$ & $\begin{array}{r}13,81 \\
9,69 \\
10,76 \\
9,73 \\
8,10 \\
5,63 \\
4,34 \\
2,75 \\
\end{array}$ & $\begin{array}{l}. \\
. \\
. \\
. \\
. \\
. \\
.\end{array}$ & $\begin{array}{l}. \\
. \\
. \\
. \\
. \\
. \\
.\end{array}$ & $\begin{array}{l}. \\
. \\
. \\
. \\
. \\
. \\
.\end{array}$ \\
\hline Czechy & $\begin{array}{l}2004 \\
2005 \\
2006 \\
2007 \\
2008 \\
2009 \\
2010 \\
2011 \\
\end{array}$ & $\begin{array}{r}848 \\
951 \\
1072 \\
1153 \\
1240 \\
1316 \\
1442 \\
1576 \\
\end{array}$ & $\begin{array}{r}11,70 \\
10,34 \\
9,83 \\
8,54 \\
7,17 \\
5,63 \\
3,95 \\
1,99 \\
\end{array}$ & $\begin{array}{l}1,4 \\
1,4 \\
1,7 \\
1,8 \\
1,9 \\
1,7 \\
1,8 \\
1,8 \\
\end{array}$ & $\begin{array}{l}2,1 \\
3,2 \\
2,2 \\
3,6 \\
3,9 \\
2,6 \\
2,7 \\
1,5^{\text {a }} \\
\end{array}$ & $\begin{array}{l}0,6 \\
0,5 \\
0,5 \\
0,9 \\
1,0 \\
1,0 \\
0,3 \\
0,4^{\mathrm{a}}\end{array}$ \\
\hline Dania & $\begin{array}{l}2004 \\
2005 \\
2006 \\
2007 \\
2008 \\
2009 \\
2010 \\
2011 \\
\end{array}$ & $\begin{array}{l}2112 \\
2278 \\
2409 \\
2524 \\
2612 \\
2874 \\
3030 \\
3334 \\
\end{array}$ & $\begin{array}{r}26,19 \\
23,49 \\
20,13 \\
17,93 \\
15,27 \\
11,28 \\
7,76 \\
3,78 \\
\end{array}$ & $\begin{array}{l}54,0 \\
56,8 \\
45,4 \\
47,1 \\
47,0 \\
41,0 \\
40,8 \\
41,3 \\
\end{array}$ & $\begin{array}{l}45,7 \\
46,5 \\
56,6 \\
50,0 \\
48,3 \\
43,1 \\
42,2 \\
39,7^{\mathrm{a}} \\
\end{array}$ & $\begin{array}{l}38,9 \\
34,0 \\
27,8 \\
38,6 \\
34,8 \\
22,5 \\
29,0 \\
32,3^{\mathrm{a}} \\
\end{array}$ \\
\hline Estonia & $\begin{array}{l}2004 \\
2005 \\
2006 \\
2007 \\
2008 \\
2009 \\
2010 \\
2011 \\
\end{array}$ & $\begin{array}{r}657 \\
759 \\
876 \\
1039 \\
1148 \\
1246 \\
1479 \\
1595 \\
\end{array}$ & $\begin{array}{r}18,89 \\
17,40 \\
12,63 \\
11,90 \\
9,27 \\
7,68 \\
5,68 \\
2,95 \\
\end{array}$ & $\begin{array}{l}0,4 \\
1,2 \\
3,7 \\
2,2 \\
2,2 \\
2,2 \\
2,2 \\
2,2 \\
\end{array}$ & $\begin{array}{r}6,4 \\
5,2 \\
9,7 \\
20,1 \\
15,7 \\
17,9 \\
12,7 \\
14,2^{\mathrm{a}} \\
\end{array}$ & $\begin{array}{l}1,4 \\
1,8 \\
6,7 \\
8,2 \\
3,7 \\
2,2 \\
2,2 \\
6,7^{\mathrm{a}} \\
\end{array}$ \\
\hline $\begin{array}{l}\text { Finlan- } \\
\text { dia }\end{array}$ & $\begin{array}{l}2004 \\
2005 \\
2006 \\
2007 \\
2008 \\
2009 \\
2010 \\
2011\end{array}$ & $\begin{array}{l}2118 \\
2285 \\
2420 \\
2492 \\
2531 \\
2675 \\
2743 \\
2871\end{array}$ & $\begin{array}{r}20,51 \\
18,12 \\
15,41 \\
14,08 \\
12,12 \\
8,86 \\
6,18 \\
3,03\end{array}$ & $\begin{array}{l}64,1 \\
65,6 \\
50,7 \\
51,0 \\
49,7 \\
50,8 \\
50,9 \\
52,0\end{array}$ & $\begin{array}{l}173,7 \\
166,4 \\
174,3 \\
154,8 \\
131,4 \\
123,4 \\
133,7 \\
151,7^{a}\end{array}$ & $\begin{array}{r}11,9 \\
9,3 \\
8,9 \\
11,3 \\
11,5 \\
9,7 \\
11,6 \\
6,9^{\mathrm{a}}\end{array}$ \\
\hline
\end{tabular}




\begin{tabular}{|c|c|c|c|c|c|c|}
\hline 1 & 2 & 3 & 4 & 5 & 6 & 7 \\
\hline Francja & $\begin{array}{l}2004 \\
2005 \\
2006 \\
2007 \\
2008 \\
2009 \\
2010 \\
2011\end{array}$ & $\begin{array}{l}1158 \\
1259 \\
1319 \\
1350 \\
1411 \\
1497 \\
1527 \\
1566 \\
\end{array}$ & $\begin{array}{r}18,26 \\
16,43 \\
14,02 \\
12,62 \\
10,39 \\
7,90 \\
5,36 \\
2,74\end{array}$ & $\begin{array}{l}38,1 \\
37,6 \\
32,0 \\
31,9 \\
31,8 \\
31,4 \\
31,1 \\
31,5\end{array}$ & $\begin{array}{l}30,1 \\
32,9 \\
29,8 \\
31,3 \\
31,5 \\
30,5 \\
30,9 \\
32,0^{\mathrm{a}}\end{array}$ & $\begin{array}{l}6,4 \\
5,7 \\
5,8 \\
6,6 \\
6,9 \\
7,7 \\
7,2 \\
8,2^{a} \\
\end{array}$ \\
\hline Grecja & $\begin{array}{l}2004 \\
2005 \\
2006 \\
2007 \\
2008 \\
2009 \\
2010 \\
2011\end{array}$ & $\begin{array}{r}903 \\
1054 \\
1217 \\
1273 \\
1367 \\
1445 \\
1454 \\
1485 \\
\end{array}$ & $\begin{array}{r}15,07 \\
13,54 \\
12,05 \\
10,44 \\
8,77 \\
6,90 \\
4,63 \\
2,35\end{array}$ & $\begin{array}{l}0,8 \\
1,4 \\
1,1 \\
1,0 \\
0,8 \\
0,8 \\
0,6 \\
0,6\end{array}$ & $\begin{array}{l}1,1 \\
2,0 \\
1,3 \\
2,2 \\
2,1 \\
1,8 \\
1,3 \\
1,5^{\mathrm{a}}\end{array}$ & $\begin{array}{l}0,3 \\
0,5 \\
0,4 \\
0,8 \\
0,7 \\
0,5 \\
0,4 \\
0,4^{\mathrm{a}}\end{array}$ \\
\hline $\begin{array}{l}\text { Hiszpa- } \\
\text { nia }\end{array}$ & $\begin{array}{l}2004 \\
2005 \\
2006 \\
2007 \\
2008 \\
2009 \\
2010 \\
2011\end{array}$ & $\begin{array}{r}942 \\
1063 \\
1156 \\
1213 \\
1279 \\
1398 \\
1479 \\
1599 \\
\end{array}$ & $\begin{array}{r}17,07 \\
15,04 \\
13,26 \\
11,84 \\
9,83 \\
7,52 \\
5,11 \\
2,81\end{array}$ & $\begin{array}{l}4,9 \\
4,9 \\
3,3 \\
3,4 \\
3,4 \\
3,5 \\
3,6 \\
3,5\end{array}$ & $\begin{array}{l}5,1 \\
5,1 \\
5,6 \\
7,5 \\
7,9 \\
8,6 \\
8,9 \\
9,9^{\text {a }}\end{array}$ & $\begin{array}{l}2,2 \\
2,7 \\
2,9 \\
3,2 \\
4,0 \\
4,1 \\
3,7 \\
4,4^{\mathrm{a}}\end{array}$ \\
\hline $\begin{array}{l}\text { Holan- } \\
\text { dia }\end{array}$ & $\begin{array}{l}2004 \\
2005 \\
2006 \\
2007 \\
2008 \\
2009 \\
2010 \\
2011 \\
\end{array}$ & $\begin{array}{l}1868 \\
2103 \\
2208 \\
2285 \\
2391 \\
2592 \\
2702 \\
2812 \\
\end{array}$ & $\begin{array}{r}25,29 \\
22,26 \\
19,43 \\
17,45 \\
14,20 \\
11,08 \\
7,57 \\
3,75 \\
\end{array}$ & $\begin{array}{l}60,5 \\
58,9 \\
55,1 \\
51,8 \\
51,0 \\
50,9 \\
46,9 \\
48,6\end{array}$ & $\begin{array}{l}94,6 \\
95,7 \\
88,4 \\
79,4 \\
75,3 \\
66,0 \\
54,8 \\
59,4^{\text {a }} \\
\end{array}$ & $\begin{array}{l}11,7 \\
13,4 \\
16,6 \\
17,5 \\
15,9 \\
14,4 \\
13,3 \\
11,9^{\mathrm{a}} \\
\end{array}$ \\
\hline Irlandia & $\begin{array}{l}2004 \\
2005 \\
2006 \\
2007 \\
2008 \\
2009 \\
2010 \\
2011 \\
\end{array}$ & $\begin{array}{l}1345 \\
1600 \\
1667 \\
1796 \\
1921 \\
2151 \\
2352 \\
2440 \\
\end{array}$ & $\begin{array}{r}18,38 \\
16,33 \\
15,72 \\
13,91 \\
11,49 \\
8,82 \\
5,96 \\
2,99 \\
\end{array}$ & $\begin{array}{l}16,2 \\
17,8 \\
14,6 \\
16,8 \\
16,2 \\
15,2 \\
14,5 \\
14,6 \\
\end{array}$ & $\begin{array}{l}27,0 \\
28,1 \\
33,3 \\
36,4 \\
36,7 \\
29,3 \\
29,4 \\
28,6^{\text {a }}\end{array}$ & $\begin{array}{r}3,7 \\
5,3 \\
5,2 \\
7,0 \\
10,5 \\
6,8 \\
3,5 \\
6,6^{\mathrm{a}} \\
\end{array}$ \\
\hline Litwa & $\begin{array}{l}2004 \\
2005 \\
2006 \\
2007 \\
2008 \\
2009 \\
2010 \\
2011\end{array}$ & $\begin{array}{l}356 \\
457 \\
520 \\
532 \\
784 \\
770 \\
801 \\
901\end{array}$ & $\begin{array}{l}9,77 \\
8,73 \\
7,94 \\
6,44 \\
4,93 \\
3,94 \\
3,11 \\
1,87 \\
\end{array}$ & $\begin{array}{l}. \\
\cdot \\
\cdot \\
\cdot \\
\cdot \\
\cdot \\
\cdot \\
.\end{array}$ & $\begin{array}{l}\cdot \\
\cdot \\
\cdot \\
\cdot \\
\cdot \\
\cdot \\
\cdot \\
\cdot\end{array}$ & $\begin{array}{l}. \\
. \\
. \\
. \\
. \\
. \\
.\end{array}$ \\
\hline $\begin{array}{l}\text { Luksem- } \\
\text { burg }\end{array}$ & $\begin{array}{l}2004 \\
2005 \\
2006 \\
2007 \\
2008 \\
2009 \\
2010 \\
2011\end{array}$ & $\begin{array}{r}240 \\
266 \\
379 \\
421 \\
567 \\
786 \\
921 \\
1133\end{array}$ & $\begin{array}{r}16,70 \\
18,00 \\
13,22 \\
9,99 \\
10,14 \\
7,91 \\
4,87 \\
2,36\end{array}$ & $\begin{array}{l}50,2 \\
43,0 \\
38,1 \\
27,0 \\
30,7 \\
24,1 \\
25,6 \\
23,1\end{array}$ & $\begin{array}{l}24,0 \\
17,2 \\
31,8 \\
16,6 \\
24,5 \\
16,1 \\
21,7 \\
27,0^{\mathrm{a}}\end{array}$ & $\begin{array}{l}4,4 \\
2,2 \\
4,2 \\
4,2 \\
4,1 \\
2,0 \\
2,0 \\
1,9^{a}\end{array}$ \\
\hline
\end{tabular}




\begin{tabular}{|c|c|c|c|c|c|c|}
\hline 1 & 2 & 3 & 4 & 5 & 6 & 7 \\
\hline Łotwa & $\begin{array}{l}2004 \\
2005 \\
2006 \\
2007 \\
2008 \\
2009 \\
2010 \\
2011 \\
\end{array}$ & $\begin{array}{r}421 \\
522 \\
456 \\
556 \\
749 \\
761 \\
848 \\
1304 \\
\end{array}$ & $\begin{array}{r}13,06 \\
13,47 \\
11,59 \\
6,07 \\
4,60 \\
4,06 \\
3,24 \\
1,17 \\
\end{array}$ & $\begin{array}{l}\dot{ } \\
\dot{ } \\
\dot{ } \\
\dot{ } \\
\dot{ } \\
\dot{ }\end{array}$ & $\begin{array}{l}\dot{ } \\
\dot{ } \\
\dot{ } \\
\dot{ } \\
\dot{ } \\
.\end{array}$ & 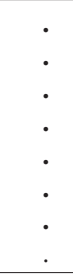 \\
\hline Malta & $\begin{array}{l}2004 \\
2005 \\
2006 \\
2007 \\
2008 \\
2009 \\
2010 \\
2011 \\
\end{array}$ & $\begin{array}{r}91 \\
139 \\
141 \\
165 \\
245 \\
232 \\
283 \\
310 \\
\end{array}$ & $\begin{array}{r}8,87 \\
13,14 \\
17,99 \\
11,06 \\
7,22 \\
4,28 \\
3,11 \\
1,85 \\
\end{array}$ & $\begin{array}{l}. \\
\dot{.} \\
\dot{ } \\
\dot{.} \\
\dot{.}\end{array}$ & $\begin{array}{l}\dot{.} \\
\dot{.} \\
\dot{.} \\
\dot{\cdot} \\
\dot{.}\end{array}$ & 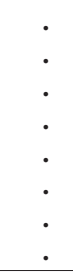 \\
\hline Niemcy & $\begin{array}{l}2004 \\
2005 \\
2006 \\
2007 \\
2008 \\
2009 \\
2010 \\
2011 \\
\end{array}$ & $\begin{array}{l}1243 \\
1381 \\
1423 \\
1462 \\
1507 \\
1594 \\
1662 \\
1736 \\
\end{array}$ & $\begin{array}{r}19,08 \\
16,96 \\
14,80 \\
13,64 \\
11,13 \\
8,63 \\
5,88 \\
3,00 \\
\end{array}$ & $\begin{array}{l}67,9 \\
69,5 \\
62,0 \\
62,1 \\
60,4 \\
60,9 \\
60,3 \\
60,9 \\
\end{array}$ & $\begin{array}{l}52,3 \\
48,2 \\
49,0 \\
51,2 \\
47,6 \\
46,3 \\
48,3 \\
48,6^{\text {a }} \\
\end{array}$ & $\begin{array}{r}10,8 \\
8,0 \\
8,0 \\
10,8 \\
8,3 \\
7,8 \\
8,3 \\
8,2^{\mathrm{a}} \\
\end{array}$ \\
\hline Polska & $\begin{array}{l}2004 \\
2005 \\
2006 \\
2007 \\
2008 \\
2009 \\
2010 \\
2011 \\
\end{array}$ & $\begin{array}{l}530 \\
595 \\
646 \\
644 \\
703 \\
730 \\
750 \\
792 \\
\end{array}$ & $\begin{array}{r}10,12 \\
8,80 \\
7,87 \\
7,47 \\
5,66 \\
4,60 \\
3,08 \\
1,72 \\
\end{array}$ & $\begin{array}{l}0,4 \\
0,3 \\
0,2 \\
0,3 \\
0,3 \\
0,1 \\
0,1 \\
0,1 \\
\end{array}$ & $\begin{array}{l}0,7 \\
0,5 \\
0,8 \\
1,0 \\
1,2 \\
1,5 \\
1,6 \\
1,5^{\mathrm{a}} \\
\end{array}$ & $\begin{array}{l}0,2 \\
0,2 \\
0,3 \\
0,4 \\
0,5 \\
0,3 \\
0,5 \\
0,4^{\mathrm{a}} \\
\end{array}$ \\
\hline $\begin{array}{l}\text { Portuga- } \\
\text { lia }\end{array}$ & $\begin{array}{l}2004 \\
2005 \\
2006 \\
2007 \\
2008 \\
2009 \\
2010 \\
2011 \\
\end{array}$ & $\begin{array}{r}648 \\
731 \\
901 \\
938 \\
1104 \\
1220 \\
1361 \\
1565 \\
\end{array}$ & $\begin{array}{r}16,98 \\
14,49 \\
12,76 \\
11,44 \\
9,47 \\
7,35 \\
4,48 \\
2,22 \\
\end{array}$ & $\begin{array}{l}0,6 \\
1,1 \\
0,9 \\
1,6 \\
1,1 \\
0,8 \\
0,8 \\
0,9 \\
\end{array}$ & $\begin{array}{l}1,0 \\
2,7 \\
2,8 \\
2,3 \\
2,7 \\
2,8 \\
3,6 \\
4,3^{\mathrm{a}} \\
\end{array}$ & $\begin{array}{l}0,3 \\
0,9 \\
1,3 \\
1,4 \\
1,4 \\
1,5 \\
0,8 \\
1,1^{\mathrm{a}} \\
\end{array}$ \\
\hline $\begin{array}{l}\text { Rumu- } \\
\text { nia }\end{array}$ & $\begin{array}{l}2004 \\
2005 \\
2006 \\
2007 \\
2008 \\
2009 \\
2010 \\
2011 \\
\end{array}$ & $\begin{array}{l}293 \\
193 \\
202 \\
274 \\
372 \\
482 \\
567 \\
568 \\
\end{array}$ & $\begin{array}{l}8,65 \\
8,02 \\
6,48 \\
5,65 \\
4,42 \\
2,77 \\
1,93 \\
1,18 \\
\end{array}$ & $\begin{array}{r}0,2 \\
0,2 \\
<0,1 \\
0,2 \\
0,1 \\
0,1 \\
0,1 \\
0,1 \\
\end{array}$ & $\begin{array}{l}0,5 \\
0,5 \\
0,8 \\
1,0 \\
1,1 \\
0,7 \\
0,7 \\
0,7^{\mathrm{a}} \\
\end{array}$ & $\begin{array}{r}0,0 \\
<0,1 \\
0,0 \\
<0,1 \\
<0,1 \\
<0,1 \\
0,0 \\
0,2^{\mathrm{a}}\end{array}$ \\
\hline $\begin{array}{l}\text { Słowa- } \\
\text { cja }\end{array}$ & $\begin{array}{l}2004 \\
2005 \\
2006 \\
2007 \\
2008 \\
2009 \\
2010 \\
2011\end{array}$ & $\begin{array}{l}580 \\
595 \\
650 \\
691 \\
802 \\
778 \\
850 \\
909\end{array}$ & $\begin{array}{l}9,92 \\
8,65 \\
9,08 \\
7,84 \\
6,05 \\
4,68 \\
3,22 \\
1,74\end{array}$ & $\begin{array}{l}0,6 \\
0,7 \\
0,6 \\
0,4 \\
0,6 \\
0,4 \\
0,6 \\
0,7\end{array}$ & $\begin{array}{l}0,7 \\
0,7 \\
1,1 \\
1,3 \\
2,8 \\
1,7 \\
2,2 \\
1,3^{\mathrm{a}}\end{array}$ & $\begin{array}{l}0,2 \\
0,0 \\
0,7 \\
0,0 \\
0,0 \\
0,2 \\
0,4 \\
0,4^{\mathrm{a}}\end{array}$ \\
\hline
\end{tabular}




\begin{tabular}{|c|c|c|c|c|c|c|}
\hline 1 & 2 & 3 & 4 & 5 & 6 & 7 \\
\hline $\begin{array}{l}\text { Słowe- } \\
\text { nia }\end{array}$ & $\begin{array}{l}2004 \\
2005 \\
2006 \\
2007 \\
2008 \\
2009 \\
2010 \\
2011\end{array}$ & $\begin{array}{l}1276 \\
1544 \\
1587 \\
1797 \\
2030 \\
2167 \\
2206 \\
2483 \\
\end{array}$ & $\begin{array}{r}10,99 \\
10,78 \\
10,82 \\
8,87 \\
7,40 \\
6,18 \\
3,98 \\
2,06\end{array}$ & $\begin{array}{l}6,0 \\
8,5 \\
3,5 \\
3,5 \\
4,0 \\
3,4 \\
3,4 \\
3,4\end{array}$ & $\begin{array}{r}6,5 \\
4,5 \\
6,5 \\
8,9 \\
10,4 \\
9,3 \\
8,8 \\
12,2^{\mathrm{a}}\end{array}$ & $\begin{array}{l}2,0 \\
2,0 \\
4,0 \\
2,0 \\
4,0 \\
3,9 \\
4,9 \\
3,4^{\mathrm{a}}\end{array}$ \\
\hline Szwecja & $\begin{array}{l}2004 \\
2005 \\
2006 \\
2007 \\
2008 \\
2009 \\
2010 \\
2011 \\
\end{array}$ & $\begin{array}{l}2392 \\
2596 \\
2652 \\
2717 \\
2679 \\
2842 \\
2978 \\
3140 \\
\end{array}$ & $\begin{array}{r}23,51 \\
21,10 \\
17,98 \\
15,96 \\
13,54 \\
10,49 \\
6,89 \\
3,39 \\
\end{array}$ & $\begin{array}{l}76,9 \\
91,5 \\
76,8 \\
79,6 \\
77,2 \\
72,7 \\
73,1 \\
74,2 \\
\end{array}$ & $\begin{array}{r}86,2 \\
94,0 \\
119,1 \\
133,7 \\
128,4 \\
111,9 \\
104,5 \\
104,7^{\mathrm{a}} \\
\end{array}$ & $\begin{array}{l}14,1 \\
13,6 \\
14,3 \\
14,5 \\
12,5 \\
12,9 \\
13,8 \\
13,1^{\text {a }} \\
\end{array}$ \\
\hline $\begin{array}{l}\text { Wielka } \\
\text { Brytania }\end{array}$ & $\begin{array}{l}2004 \\
2005 \\
2006 \\
2007 \\
2008 \\
2009 \\
2010 \\
2011\end{array}$ & $\begin{array}{l}1802 \\
1981 \\
2095 \\
2159 \\
2156 \\
2286 \\
2345 \\
2419\end{array}$ & $\begin{array}{r}22,11 \\
19,15 \\
16,33 \\
14,46 \\
12,14 \\
9,18 \\
6,04 \\
3,04\end{array}$ & $\begin{array}{l}27,4 \\
27,3 \\
24,8 \\
23,5 \\
22,8 \\
22,5 \\
22,1 \\
21,9\end{array}$ & $\begin{array}{l}35,5 \\
34,2 \\
36,8 \\
35,3 \\
31,4 \\
26,5 \\
26,5 \\
25,4^{\mathrm{a}}\end{array}$ & $\begin{array}{l}7,4 \\
8,2 \\
7,1 \\
7,3 \\
6,6 \\
6,1 \\
6,1 \\
5,4^{\mathrm{a}}\end{array}$ \\
\hline Węgry & $\begin{array}{l}2004 \\
2005 \\
2006 \\
2007 \\
2008 \\
2009 \\
2010 \\
2011 \\
\end{array}$ & $\begin{array}{l}630 \\
725 \\
734 \\
766 \\
838 \\
823 \\
828 \\
907 \\
\end{array}$ & $\begin{array}{r}15,66 \\
13,21 \\
11,33 \\
10,55 \\
8,05 \\
6,45 \\
4,45 \\
2,32 \\
\end{array}$ & $\begin{array}{l}4,4 \\
4,1 \\
3,2 \\
3,6 \\
3,6 \\
3,5 \\
3,5 \\
3,4 \\
\end{array}$ & $\begin{array}{l}4,7 \\
4,0 \\
6,4 \\
6,6 \\
6,8 \\
6,0 \\
5,3 \\
4,3^{\mathrm{a}} \\
\end{array}$ & $\begin{array}{l}1,2 \\
0,9 \\
1,1 \\
1,2 \\
1,4 \\
1,3 \\
1,0 \\
0,9^{\mathrm{a}} \\
\end{array}$ \\
\hline Włochy & $\begin{array}{l}2004 \\
2005 \\
2006 \\
2007 \\
2008 \\
2009 \\
2010 \\
2011\end{array}$ & $\begin{array}{r}922 \\
1006 \\
1077 \\
1144 \\
1192 \\
11261 \\
1284 \\
1334\end{array}$ & $\begin{array}{r}18,61 \\
16,95 \\
14,34 \\
12,76 \\
10,72 \\
8,19 \\
5,57 \\
2,81\end{array}$ & $\begin{array}{r}12,8 \\
12,6 \\
10,5 \\
10,4 \\
10,2 \\
9,9 \\
9,9 \\
9,8\end{array}$ & $\begin{array}{l}8,4 \\
8,7 \\
9,7 \\
9,6 \\
9,2 \\
8,9 \\
8,9 \\
9,1^{\mathrm{a}}\end{array}$ & $\begin{array}{l}2,5 \\
2,7 \\
2,5 \\
2,5 \\
3,0 \\
2,7 \\
2,6 \\
1,8^{\mathrm{a}}\end{array}$ \\
\hline
\end{tabular}

Wyjaśnienia: ${ }^{a}$ są to dane oparte o szacunki Sekretariatu OECD oraz prognozy pochodzące ze źródeł narodowych; ${ }^{\mathrm{b}}$ są to patenty uzyskane stosownie do zasad traktatu PCT.

Źródła: http://www.scimagojr.com/countryrank; OECD (2011), Main and Science and Technology Indicators, vol. 2010/2, Paris 2011, s. 90, 91 i 144; OECD (2013), Main and Science and Technology Indicators, vol. 2013/1, Paris 2013, s. 84, 86, 87 i 124; Europe in figures - Eurostat yearbook 2008, s. 25; Europe in figures - Eurostat yearbook 2009, s. 137; Europe in figures - Eurostat yearbook 2010, s. 163; Europe in figures - Eurostat yearbook 2011, s. 126; Europe in figures - Eurostat yearbook 2012, s. 122; pl.wikipedia.org/wiki/Bułgaria; pl.wikipedia.org/wiki/Cyprus; pl.wikipedia.org/wiki/Litwa; obliczenia własne.

\section{Czynniki oddziaływujące na pozycję Polski w zakresie B+R w Unii Europejskiej}

O prezentowaniu przez Polskę bardzo słabej pozycji w zakresie prac badawczych i rozwojowych w UE zaważyło kilka czynników. Szczególne znaczenie miał poziom 
intensywności badawczo-rozwojowej. Wiele ze starych państw członkowskich wykazywało znacznie wyższą intensywność niż Polska, przy czym najwyższą przewagę osiagnęły dwa państwa skandynawskie - Finlandia i Szwecja. Przewaga ta sięgała (w latach 2004-2011) odpowiednio od 2,89-3,02 punktu procentowego oraz od 3,06-2,61 punktu (patrz tabela 2).

Warto tu podkreślić, że obydwa skandynawskie państwa są jedynymi krajami w ugrupowaniu, które przez cały okres 2004-2011 przekraczały już przewidziany w strategii lizbońskiej dla ogólnych wydatków badawczo-rozwojowych wskaźnik 3\% PKB. Zasadniczym celem tej strategii, której poszczególne elementy zostały ustalone na szeregu posiedzeniach Rady Europejskiej, począwszy od posiedzenia w Lizbonie w marcu 2000 r., jest przekształcenie gospodarki Unii Europejskiej do 2010 r. ,w najbardziej dynamiczną i opartą na wiedzy gospodarkę na świecie, zdolną do trwałego wzrostu gospodarczego, powiązanego ze wzrostem zatrudnienia, rosnącą kohezją społeczną i poszanowaniem dla środowiska naturalnego". W 2009 r. wskaźnik ten przekroczyła też Dania (patrz tabela 2).

Spośród analizowanych nowych państw członkowskich jedynie w Rumunii i Słowacji udział ogólnych wydatków na B+R w PKB był niższy w Polsce, a wyższy w Czechach, Estonii, Słowenii i na Węgrzech. W Estonii i Słowenii nastąpił szczególnie silny wzrost intensywności badawczo-rozwojowej w latach 2006-2011, a mianowicie odpowiednio o 1,28 i 0,91 punktu procentowego (patrz tabela 2).

Kolejnym szczególnie ważnym czynnikiem, który wpłynął na bardzo niską pozycję Polski w zakresie B+R była występująca tam struktura źródeł ich finansowania. Charakterystyczna była dla niej dominująca rola państwa w ponoszeniu kosztów tych prac, co było sytuacją niekorzystną z punktu widzenia rozwoju nauki. W finansowaniu prac badawczych i rozwojowych uczestniczyły również firmy, inne krajowe instytucje naukowe oraz zagranica (patrz tabela 2). Przez zagranicę rozumiano w szczególności organizacje międzynarodowe, np. Unię Europejską. Popierała ona B+R w ramach unijnych (ramowych) programów badań i rozwoju technologicznego. Przedsiębiorstwa wydawały spośród tych trzech rodzajów podmiotów najwyższe środki.

Odmiennie niż w Polsce w większości starych państw członkowskich firmy przodowały w zakresie finansowania $\mathrm{B}+\mathrm{R}$ (patrz tabela 2). Udział ich był najwyższy w Finlandii, gdzie w latach 2004-2011 sięgał przeciętnie 67,8\%. Również w niektórych nowych krajach członkowskich, tzn. w Republice Czeskiej, w Słowenii i na Węgrzech (od 2008 r.) przedsiębiorstwa były najważniejszymi podmiotami popierającymi prace badawcze i rozwojowe. Natomiast Słowacja i Rumunia wykazywały strukturę źródeł finansowania $\mathrm{B}+\mathrm{R}$ zbliżoną do polskiej.

Rodzić się tu musi pytanie, jakie uwarunkowania zaważyły na ograniczonym popieraniu przez firmy w Polsce prac badawczych i rozwojowych. Pierwsze z tych uwarunkowań to struktura firm wyodrębnianych z punktu widzenia ich wielkości i zaawansowania technologicznego. W Polsce działa bardzo dużo mikroprzedsiębiorstw. Są to podmioty gospodarcze zatrudniające mniej niż 10 pracowników, o rocznym obrocie oraz/lub o całkowitym bilansie rocznym nie przekraczającym $2 \mathrm{mln}$ euro, a także nie powiązane kapitałowo lub osobowo z innymi podmiotami. W latach 2009-2010 należało do tych firm ponad 1,654 mln przedsiębiorstw, czyli 96\% wszystkich firm. Mikrofirmy funkcjonują głównie w handlu i usługach, a w mniejszym stopniu w przemyśle i budownic- 
twie (Gorynia-Pfeffer, 2012, s. 196; Orłowska, s. 1). Nie są one w stanie praktycznie prowadzić B+R.

W strukturze gospodarki polskiej dominują firmy o technologiach średnio-niskich i niskich. Realizacja tu prac badawczych i rozwojowych nie jest związana z wydatkowaniem dużych środków. Kolejny czynnik to zbyt mały nacisk na eksport (Gorynia-Pfeffer, 2012, s. 196). Nie dotyczy to zasadniczo firm z udziałem kapitału zagranicznego prowadzących ożywioną wymianę handlową zwłaszcza z krajem, w którym ma siedzibę przedsiębiorstwo-matka. Położenie większego nacisku na eksport wymagałoby podjęcia szeroko zakrojonych działań zmierzających do zwiększenia międzynarodowej konkurencyjności przedsiębiorstw, $\mathrm{w}$ tym do wzmożenia realizacji $\mathrm{B}+\mathrm{R} \mathrm{w}$ firmach.

Wiele firm o czysto polskim kapitale uważa, że opłaca się bardziej dokonać za granicą zakupu licencji niż realizować własne prace badawcze i rozwojowe. Podobnie zachowuje się część firm z udziałem kapitału zagranicznego, opierających proces innowacyjny w przeważającej mierze na innowacjach pochodzących z przedsiębiorstw-matek. Pozostałe przeznaczały na B+R np. w latach 2008-2011 od 9,6 do 13,7\% ogólnych wydatków na B+R (Główny Urząd Statystyczny, Nauka i technika w 2012 r., s. 65; OECD, Main and Science and Technology Indicators, vol. 2008/2, s. 20 i 122).

Tabela 2

Wielkość ogólnych wydatków na B+R i udział w ich finansowaniu poszczególnych podmiotów w Polsce i w innych krajach czlonkowskich Unii

\begin{tabular}{|c|c|c|c|c|c|c|c|}
\hline \multirow[b]{2}{*}{ Kraj } & \multirow[b]{2}{*}{ Rok } & \multirow{2}{*}{$\begin{array}{c}\text { Ogólne wy- } \\
\text { datki na } \\
B+R^{a}\end{array}$} & \multirow{2}{*}{$\begin{array}{c}\text { Intensywność } \\
\text { badawczo- } \\
\text {-rozwojowa } \\
\text { (w \% PKB) }\end{array}$} & \multicolumn{4}{|c|}{$\begin{array}{l}\text { Udzial poszczególnych podmiotów w finansowaniu } \\
\text { ogólnych wydatków na } B+R(\mathbf{w} \%)^{\mathrm{b}}\end{array}$} \\
\hline & & & & firmy & państwo & $\begin{array}{l}\text { inne źródla } \\
\text { narodowe }\end{array}$ & zagranica \\
\hline 1 & 2 & 3 & 4 & 5 & 6 & 7 & 8 \\
\hline Austria & $\begin{array}{l}2004 \\
2005 \\
2006 \\
2007 \\
2008 \\
2009 \\
2010 \\
2011 \\
\end{array}$ & $\begin{array}{l}6011,8 \\
6835,9^{c} \\
7368,9 \\
7916,8^{c} \\
8854,1^{c} \\
8811,1 \\
9449,3^{c} \\
9761,0^{c, e} \\
\end{array}$ & $\begin{array}{l}2,26 \\
2,44^{\mathrm{c}} \\
2,44 \\
2,51 \\
2,67^{\mathrm{c}} \\
2,71 \\
2,79^{\mathrm{c}} \\
2,75^{\mathrm{c}, \mathrm{e}}\end{array}$ & $\begin{array}{l}47,2 \\
45,7^{\mathrm{c}} \\
48,4 \\
48,7 \\
46,1^{\mathrm{c}} \\
47,1 \\
44,7^{\mathrm{c}} \\
45,5^{\mathrm{c}, \mathrm{e}} \\
\end{array}$ & $\begin{array}{l}32,6 \\
36,2^{\mathrm{c}} \\
32,3 \\
32,3 \\
37,0^{\mathrm{c}, \mathrm{d}} \\
34,9 \\
38,7^{\mathrm{c}, \mathrm{d}} \\
38,1^{\mathrm{c}, \mathrm{d}, \mathrm{e}}\end{array}$ & $\begin{array}{l}0,9 \\
0,4^{\mathrm{c}} \\
1,0 \\
1,1 \\
0,4^{\mathrm{c}} \\
1,2 \\
0,5^{\mathrm{c}} \\
0,6^{\mathrm{c}, \mathrm{e}}\end{array}$ & $\begin{array}{l}19,4 \\
17,7^{\mathrm{c}} \\
18,4 \\
17,9^{\mathrm{c}} \\
16,4^{\mathrm{c}} \\
16,8^{\mathrm{c}} \\
16,1^{\mathrm{c}} \\
15,9^{\mathrm{c}, \mathrm{e}}\end{array}$ \\
\hline Belgia & $\begin{array}{l}2004 \\
2005 \\
2006 \\
2007 \\
2008 \\
2009 \\
2010 \\
2011 \\
\end{array}$ & $\begin{array}{l}6035,6 \\
6176,7 \\
6704,1 \\
7 \quad 167,9 \\
7799,3 \\
8000,0 \\
8265,0 \\
8179,4^{\mathrm{e}} \\
\end{array}$ & $\begin{array}{l}1,87 \\
1,84 \\
1,86 \\
1,89 \\
1,97 \\
2,03 \\
2,00 \\
2,04^{\mathrm{e}} \\
\end{array}$ & $\begin{array}{c}60,2 \\
59,7 \\
61,0 \\
61,4 \\
61,0 \\
58,6 \\
. \\
. \\
\end{array}$ & $\begin{array}{c}24,4 \\
24,7 \\
22,4 \\
22,2 \\
23,2 \\
25,3 \\
. \\
. \\
\end{array}$ & $\begin{array}{l}3,2 \\
3,3 \\
3,3 \\
3,5 \\
3,5 \\
4,0 \\
. \\
.\end{array}$ & $\begin{array}{c}12,3 \\
12,4 \\
13,3 \\
13,0 \\
12,3 \\
12,1 \\
. \\
. \\
\end{array}$ \\
\hline Czechy & $\begin{array}{l}2004 \\
2005 \\
2006 \\
2007 \\
2008 \\
2009 \\
2010 \\
2011\end{array}$ & 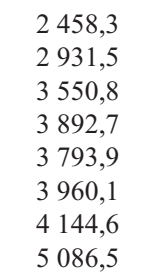 & $\begin{array}{l}1,25 \\
1,41 \\
1,49 \\
1,48 \\
1,41 \\
1,47 \\
1,56 \\
1,85\end{array}$ & $\begin{array}{l}52,8 \\
54,1 \\
56,4 \\
52,5 \\
51,1 \\
44,6 \\
48,9 \\
46,9\end{array}$ & $\begin{array}{l}41,9 \\
40,9 \\
39,0 \\
41,2 \\
41,3 \\
43,9 \\
39,9 \\
37,0\end{array}$ & $\begin{array}{l}1,6 \\
1,1 \\
1,1 \\
0,8 \\
1,2 \\
1,1 \\
0,8 \\
0,8\end{array}$ & $\begin{array}{r}3,7 \\
4,0 \\
3,6 \\
5,5 \\
6,5 \\
10,4 \\
10,4 \\
15,2\end{array}$ \\
\hline
\end{tabular}




\begin{tabular}{|c|c|c|c|c|c|c|c|}
\hline 1 & 2 & 3 & 4 & 5 & 6 & 7 & 8 \\
\hline Dania & $\begin{array}{l}2004 \\
2005 \\
2006 \\
2007 \\
2008 \\
2009 \\
2010 \\
2011 \\
\end{array}$ & $\begin{array}{l}4341,2 \\
4456,8 \\
4849,5 \\
5311,2^{\text {f }} \\
6235,8 \\
6679,7 \\
6910,4 \\
7052,4^{c, e} \\
\end{array}$ & $\begin{array}{l}2,48 \\
2,45 \\
2,48 \\
2,58^{\text {f }} \\
2,85 \\
3,16 \\
3,07 \\
3,09^{\mathrm{c}, \mathrm{e}} \\
\end{array}$ & $\begin{array}{c}59,5 \\
\cdot \\
61,0^{\mathrm{f}} \\
\cdot \\
62,1 \\
60,7^{\mathrm{c}} \\
60,2^{\mathrm{c}, \mathrm{e}}\end{array}$ & $\begin{array}{c}27,6 \\
\cdot \\
25,9^{\mathrm{d}, \mathrm{f}} \\
\cdot \\
26,1 \\
27,1^{\mathrm{c}} \\
27,6^{\mathrm{c}, \mathrm{e}}\end{array}$ & $\begin{array}{l}2,8 \\
\dot{3,5^{\mathrm{f}}} \\
\dot{3}, 1 \\
3,5^{\mathrm{c}} \\
3,5^{\mathrm{c}, \mathrm{e}}\end{array}$ & $\begin{array}{c}10,1 \\
\cdot \\
9,5^{\mathrm{f}} \\
\cdot \\
8,6 \\
8,7^{\mathrm{c}} \\
8,7^{\mathrm{c}, \mathrm{c}}\end{array}$ \\
\hline Estonia & $\begin{array}{l}2004 \\
2005 \\
2006 \\
2007 \\
2008 \\
2009 \\
2010 \\
2011 \\
\end{array}$ & $\begin{array}{c}\cdot \\
289,9 \\
312,9 \\
379.1 \\
374,3 \\
437,6 \\
710,4 \\
\end{array}$ & $\begin{array}{l}\cdot \\
\cdot \\
1,13 \\
1,08 \\
1,28 \\
1,43 \\
1,63 \\
2,41\end{array}$ & $\begin{array}{c}\cdot \\
\cdot \\
38,1 \\
41,6 \\
39,8 \\
38,5 \\
43,6 \\
55,0\end{array}$ & $\begin{array}{c}\cdot \\
44,6 \\
45,6 \\
50,0 \\
48,8 \\
44,1 \\
32,8 \\
\end{array}$ & $\begin{array}{l}\cdot \\
\cdot \\
1,0 \\
1,0 \\
0,8 \\
1,4 \\
0,8 \\
0,4 \\
\end{array}$ & $\begin{array}{r}\cdot \\
\cdot \\
16,3 \\
11,7 \\
9,4 \\
11,3 \\
11,4 \\
11,9\end{array}$ \\
\hline Finlandia & $\begin{array}{l}2004 \\
2005 \\
2006 \\
2007 \\
2008 \\
2009 \\
2010 \\
2011 \\
\end{array}$ & 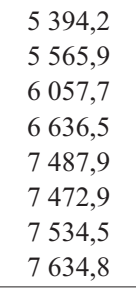 & $\begin{array}{l}3,45 \\
3,48 \\
3,48 \\
3,47 \\
3,70 \\
3,94 \\
3,90 \\
3,78 \\
\end{array}$ & $\begin{array}{l}69,3 \\
66,9 \\
66,6 \\
68,2 \\
70,3 \\
68,1 \\
66,1 \\
67,0\end{array}$ & $\begin{array}{l}26,3 \\
25,7 \\
25,1 \\
24,1 \\
21,8 \\
24,0 \\
25,7 \\
25,0^{f} \\
\end{array}$ & $\begin{array}{l}1,2 \\
1,2 \\
1,2 \\
1,2 \\
1,2 \\
1,3 \\
1,3 \\
1,4 \\
\end{array}$ & $\begin{array}{l}3,2 \\
6,3^{\text {f }} \\
7,1 \\
6,5 \\
6,6 \\
6,6 \\
6,9 \\
6,5\end{array}$ \\
\hline Francja & $\begin{array}{l}2004 \\
2005 \\
2006 \\
2007 \\
2008 \\
2009 \\
2010 \\
2011 \\
\end{array}$ & $\begin{array}{l}38024,8 \\
39270,1 \\
41940,7 \\
44011,9 \\
46547,8 \\
49479,8 \\
49934,3^{\text {a }} \\
51891,0\end{array}$ & $\begin{array}{l}2,15^{\mathrm{f}} \\
2,10 \\
2,11 \\
2,08 \\
2,12 \\
2,27 \\
2,24^{\mathrm{f}} \\
2,24 \\
\end{array}$ & $\begin{array}{l}50,7^{\text {f }} \\
51,9 \\
52,3 \\
52,3 \\
50,8 \\
52,3 \\
53,5^{\text {f }} \\
.\end{array}$ & $\begin{array}{l}38,7^{\mathrm{f}} \\
38,6 \\
38,5 \\
38,1 \\
38,9 \\
38,7 \\
37,0^{\mathrm{f}} \\
.\end{array}$ & $\begin{array}{l}1,8^{\mathrm{f}} \\
1,9 \\
2,2 \\
2,1 \\
2,3 \\
2,0 \\
1,8^{\mathrm{f}} \\
. \\
\end{array}$ & $\begin{array}{l}8,8^{\mathrm{f}} \\
7,5 \\
7,0 \\
7,5 \\
8,0 \\
7,0 \\
7,6^{\mathrm{f}} \\
.\end{array}$ \\
\hline Grecja & $\begin{array}{l}2004 \\
2005 \\
2006 \\
2007 \\
\end{array}$ & $\begin{array}{l}1470,6^{\mathrm{c}} \\
1642,7 \\
1746,6^{\mathrm{c}} \\
1866,8^{\mathrm{c}} \\
\end{array}$ & $\begin{array}{l}0,55 \\
0,58 \\
0,59^{\mathrm{c}} \\
0,60^{\mathrm{c}}\end{array}$ & $\begin{array}{c}\cdot \\
31,1 \\
\cdot \\
\cdot\end{array}$ & $\begin{array}{c}\cdot \\
46,8 \\
\cdot \\
\cdot\end{array}$ & $\begin{array}{l}3,1 \\
\cdot \\
\end{array}$ & $\begin{array}{c}\cdot \\
19,0 \\
\cdot\end{array}$ \\
\hline $\begin{array}{l}\text { Hiszpa- } \\
\text { nia }\end{array}$ & $\begin{array}{l}2004 \\
2005 \\
2006 \\
2007 \\
2008 \\
2009 \\
2010 \\
2011 \\
\end{array}$ & $\begin{array}{l}11799,5 \\
13283,9 \\
16042,7 \\
18314,9 \\
20414,9^{f} \\
20440,2 \\
20232,5 \\
19763,1\end{array}$ & $\begin{array}{l}1,06 \\
1,12 \\
1,20 \\
1,27 \\
1,35^{\mathrm{f}} \\
1,39 \\
1,39 \\
1,33 \\
\end{array}$ & $\begin{array}{l}48,0 \\
46,3 \\
47,1 \\
45,5 \\
45,0^{\mathrm{f}} \\
43,4 \\
43,0 \\
.\end{array}$ & $\begin{array}{l}41,0 \\
43,0 \\
42,5 \\
43,7 \\
45,6^{\mathrm{f}} \\
47,1 \\
46,6 \\
.\end{array}$ & $\begin{array}{l}4,8 \\
5,0 \\
4,5 \\
3,9 \\
3,8^{\mathrm{f}} \\
4,1 \\
4,6 \\
.\end{array}$ & $\begin{array}{l}6,2 \\
5,7 \\
5,9 \\
7,0 \\
5,7^{\mathrm{f}} \\
5,5 \\
5,7 \\
.\end{array}$ \\
\hline Holandia & $\begin{array}{l}2004 \\
2005 \\
2006 \\
2007 \\
2008 \\
2009 \\
2010 \\
2011\end{array}$ & $\begin{array}{r}9643,0 \\
9843,2^{\mathrm{e}} \\
11707,3 \\
12061,0 \\
12467,8 \\
12301,2 \\
12801,1 \\
.\end{array}$ & $\begin{array}{l}1,78 \\
1,90 \\
1,74^{\mathrm{e}} \\
1,81 \\
1,77 \\
1,82 \\
1,85 \\
.\end{array}$ & $\begin{array}{c}\cdot \\
\cdot \\
\dot{\cdot} \\
48,8 \\
\dot{\cdot} \\
45,1 \\
\cdot \\
\cdot\end{array}$ & $\begin{array}{c}\cdot \\
\cdot \\
\cdot \\
38,0 \\
\cdot \\
40,9 \\
\cdot \\
\cdot\end{array}$ & $\begin{array}{l}\cdot \\
\cdot \\
2,5 \\
\dot{3}, 1 \\
\cdot \\
\cdot\end{array}$ & $\begin{array}{c}\cdot \\
\cdot \\
10,7 \\
\cdot \\
10,8 \\
\cdot \\
\cdot\end{array}$ \\
\hline
\end{tabular}




\begin{tabular}{|c|c|c|c|c|c|c|c|}
\hline 1 & 2 & 3 & 4 & 5 & 6 & 7 & 8 \\
\hline Irlandia & $\begin{array}{l}2004 \\
2005 \\
2006 \\
2007 \\
2008 \\
2009 \\
2010 \\
2011 \\
\end{array}$ & $\begin{array}{l}1831,9 \\
1984,8 \\
2249,9 \\
2537,4 \\
2738,4 \\
3049,6 \\
3130,4^{c} \\
3223,0^{c} \\
\end{array}$ & $\begin{array}{l}1,24 \\
1,26 \\
1,25 \\
1,29 \\
1,46 \\
1,70 \\
1,71^{\circ} \\
1,70^{\circ}\end{array}$ & $\begin{array}{l}58,6 \\
57,4 \\
53,4 \\
49,5 \\
48,8 \\
52,1 \\
52,2^{\mathrm{c}} \\
48,3^{\mathrm{c}} \\
\end{array}$ & $\begin{array}{l}31,1 \\
32,0 \\
31,9 \\
32,4 \\
33,7 \\
29,8 \\
29,4^{\mathrm{c}} \\
30,3^{\mathrm{c}} \\
\end{array}$ & $\begin{array}{l}1,7 \\
1,9 \\
1,8 \\
2,2 \\
2,0 \\
1,6 \\
1,4^{\mathrm{c}} \\
1,3^{\mathrm{c}}\end{array}$ & $\begin{array}{r}8,6 \\
8,6 \\
12,9 \\
15,8 \\
15,6 \\
16,5 \\
17,0^{c} \\
20,1^{c} \\
\end{array}$ \\
\hline $\begin{array}{l}\text { Luksem- } \\
\text { burg }\end{array}$ & $\begin{array}{l}2004 \\
2005 \\
2006 \\
2007 \\
2008 \\
2009 \\
2010 \\
2011 \\
\end{array}$ & $\begin{array}{l}485,9 \\
511,7 \\
615,5 \\
639,9^{\mathrm{c}} \\
682,8 \\
680,1 \\
637,0 \\
656,2^{\mathrm{c}, \mathrm{e}} \\
\end{array}$ & $\begin{array}{l}1,63 \\
1,57 \\
1,66 \\
1,58^{\mathrm{c}} \\
1,66 \\
1,72 \\
1,48 \\
1,43^{\mathrm{c}, \mathrm{e}}\end{array}$ & $\begin{array}{c}79,7 \\
\dot{76,0^{\mathrm{c}}} \\
\dot{70,3} \\
44,3 \\
46,1^{\mathrm{c}, \mathrm{e}}\end{array}$ & $\begin{array}{c}- \\
16,6 \\
\dot{18,2^{\mathrm{c}}} \\
\dot{2} \\
24,3 \\
34,8 \\
33,9^{\mathrm{c}, \mathrm{e}} \\
\end{array}$ & $\begin{array}{l}0,1 \\
\dot{0,1^{\mathrm{c}}} \\
\dot{0} \\
0,1 \\
0,2 \\
0,2^{\mathrm{c}, \mathrm{e}}\end{array}$ & $\begin{array}{c}3,6 \\
\dot{5}, 7^{\mathrm{c}} \\
\dot{\cdot} \\
5,4 \\
20,7 \\
19,9^{\mathrm{c}, \mathrm{e}} \\
\end{array}$ \\
\hline Polska & $\begin{array}{l}2004 \\
2005 \\
2006 \\
2007 \\
2008 \\
2009 \\
2010 \\
2011 \\
\end{array}$ & $\begin{array}{l}2773,6 \\
2936,4 \\
3191,8 \\
3620,4 \\
4150,9 \\
4837,6 \\
5625,3 \\
6227,9 \\
\end{array}$ & $\begin{array}{l}0,56 \\
0,57 \\
0,56 \\
0,57 \\
0,60 \\
0,67 \\
0,74 \\
0,76 \\
\end{array}$ & $\begin{array}{l}30,5 \\
33,4 \\
33,1 \\
34,3 \\
30,5 \\
27,1 \\
24,4 \\
28,1 \\
\end{array}$ & $\begin{array}{l}61,7 \\
57,7 \\
57,5 \\
58,6 \\
59,8 \\
60,4 \\
60,9 \\
55,8 \\
\end{array}$ & $\begin{array}{l}2,7 \\
3,2 \\
2,5 \\
0,4 \\
4,3 \\
7,0 \\
2,8 \\
2,7 \\
\end{array}$ & $\begin{array}{r}5,2 \\
5,7 \\
7,0 \\
6,7 \\
5,4 \\
5,5 \\
11,8 \\
13,4 \\
\end{array}$ \\
\hline $\begin{array}{l}\text { Portuga- } \\
\text { lia }\end{array}$ & $\begin{array}{l}2004 \\
2005 \\
2006 \\
2007 \\
2008 \\
2009 \\
2010 \\
2011\end{array}$ & $\begin{array}{l}1552,7^{\mathrm{c}} \\
1697,9 \\
2395,1^{\mathrm{c}} \\
2989,6 \\
3981,9^{\mathrm{f}} \\
4340,9 \\
4321,1 \\
4037,6^{\mathrm{e}}\end{array}$ & $\begin{array}{l}0,77^{\mathrm{c}} \\
0,81 \\
0,99^{\mathrm{c}} \\
1,17^{\mathrm{c}} \\
1,50^{\mathrm{f}} \\
1,64 \\
1,59 \\
1,49^{\mathrm{e}}\end{array}$ & $\begin{array}{l}34,2^{\mathrm{c}} \\
36,3 \\
43,0^{\mathrm{c}} \\
47,0 \\
48,1^{\mathrm{f}} \\
44,0 \\
44,1 \\
.\end{array}$ & $\begin{array}{l}57,5^{\mathrm{c}} \\
55,2 \\
48,6^{\mathrm{c}} \\
44,6 \\
43,7^{\mathrm{f}} \\
45,3 \\
44,9 \\
.\end{array}$ & $\begin{array}{l}3,5^{\mathrm{c}} \\
3,8^{\mathrm{c}} \\
3,3^{\mathrm{c}} \\
3,0 \\
5,2^{\mathrm{f}} \\
6,6 \\
7,8 \\
.\end{array}$ & $\begin{array}{l}4,8^{\mathrm{c}} \\
4,7 \\
5,2^{\mathrm{c}} \\
5,4 \\
3,0^{\mathrm{f}} \\
4,1 \\
3,2 \\
.\end{array}$ \\
\hline RFN & $\begin{array}{l}2004 \\
2005 \\
2006 \\
2007 \\
2008 \\
2009 \\
2010 \\
2011 \\
\end{array}$ & $\begin{array}{l}61393,1 \\
62448,4 \\
70108,1 \\
74016,5 \\
81 \quad 970,7 \\
82360,7 \\
86279,8 \\
93005,5^{c} \\
\end{array}$ & $\begin{array}{l}2,49 \\
2,48 \\
2,54 \\
2,53 \\
2,69 \\
2,82 \\
2,80 \\
2,86^{\mathrm{C}} \\
\end{array}$ & $\begin{array}{c}66,6 \\
67,6 \\
68,3 \\
68,1 \\
67,3 \\
66,1 \\
65,6 \\
\end{array}$ & $\begin{array}{l}30,5 \\
28,4 \\
27,5 \\
27,5 \\
28,4 \\
29,8 \\
30,3\end{array}$ & $\begin{array}{l}0,4 \\
0,3 \\
0,4 \\
0,4 \\
0,3 \\
0,3 \\
0,2 \\
.\end{array}$ & $\begin{array}{l}2,5 \\
3,7 \\
3,8 \\
4,0 \\
4,0 \\
3,8 \\
3,9 \\
.\end{array}$ \\
\hline Rumunia & $\begin{array}{l}2004 \\
2005 \\
2006 \\
2007 \\
2008 \\
2009 \\
2010 \\
2011 \\
\end{array}$ & $\begin{array}{l}1092,4 \\
1442,3 \\
1866,6 \\
1485,9 \\
1466,0 \\
1648,5^{\mathrm{f}}\end{array}$ & $\begin{array}{l}\cdot \\
0,45 \\
0,52 \\
0,58 \\
0,47 \\
0,46 \\
0,50^{\mathrm{f}} \\
\end{array}$ & $\begin{array}{c}. \\
30,4 \\
26,9 \\
23,3 \\
34,8 \\
32,3 \\
37,4^{\mathrm{f}} \\
\end{array}$ & $\begin{array}{l}64,1 \\
67,1 \\
70,1 \\
54,9 \\
54,4 \\
49,1^{\text {f }} \\
\end{array}$ & $\begin{array}{l}\cdot \\
1,4 \\
1,4 \\
2,7 \\
2,0 \\
2,2 \\
1,4^{\mathrm{f}}\end{array}$ & $\begin{array}{c}\cdot \\
4,1 \\
4,5 \\
4,0 \\
8,3 \\
11,1 \\
12,1^{\mathrm{f}} \\
\end{array}$ \\
\hline Słowacja & $\begin{array}{l}2004 \\
2005 \\
2006 \\
2007 \\
2008 \\
2009 \\
2010 \\
2011\end{array}$ & $\begin{array}{l}404,3 \\
436,3 \\
481,6 \\
517,9 \\
594,1 \\
589,5 \\
796,1 \\
882,3\end{array}$ & $\begin{array}{l}0,51 \\
0,51 \\
0,49 \\
0,46 \\
0,47 \\
0,48 \\
0,63 \\
0,68\end{array}$ & $\begin{array}{l}38,3 \\
36,6 \\
35,0 \\
35,6 \\
34,7 \\
35,1 \\
35,1 \\
33,9\end{array}$ & $\begin{array}{l}57,1^{\mathrm{g}} \\
57,0^{\mathrm{g}} \\
55,6^{\mathrm{g}} \\
53,9^{\mathrm{g}} \\
52,3^{\mathrm{g}} \\
50,6^{\mathrm{g}} \\
49,6^{\mathrm{g}} \\
49,8^{\mathrm{g}}\end{array}$ & $\begin{array}{l}0,3 \\
0,3 \\
0,4 \\
0,2 \\
0,7 \\
1,6 \\
0,7 \\
2,2\end{array}$ & $\begin{array}{r}4,3 \\
6,0 \\
9,1 \\
10,2 \\
12,3 \\
12,8 \\
14,7 \\
14,2\end{array}$ \\
\hline
\end{tabular}




\begin{tabular}{|c|c|c|c|c|c|c|c|}
\hline 1 & 2 & 3 & 4 & 5 & 6 & 7 & 8 \\
\hline Słowenia & $\begin{array}{l}2004 \\
2005 \\
2006 \\
2007 \\
2008 \\
2009 \\
2010 \\
2011\end{array}$ & $\begin{array}{c}\cdot \\
795,0 \\
795,3 \\
972,6^{\mathrm{f}} \\
1013,7 \\
1143,8 \\
1387,8^{\mathrm{f}}\end{array}$ & $\begin{array}{l}\cdot \\
\cdot \\
1,56 \\
1,45 \\
1,66^{\mathrm{f}} \\
1,85 \\
2,09 \\
2,47^{\mathrm{f}}\end{array}$ & $\begin{array}{c}\cdot \\
59,3 \\
58,3 \\
62,8^{\mathrm{f}} \\
58,0 \\
58,4 \\
61,2^{\mathrm{f}}\end{array}$ & $\begin{array}{l}\cdot \\
34,4 \\
35,6 \\
31,3^{\mathrm{f}} \\
35,7 \\
35,3 \\
31,5^{\mathrm{f}}\end{array}$ & $\begin{array}{l}\cdot \\
0,5 \\
0,4 \\
0,3^{\text {f }} \\
0,3 \\
0,3 \\
0,2^{\text {f }}\end{array}$ & $\begin{array}{l}\cdot \\
\cdot \\
5,8 \\
5,8 \\
5,6^{\mathrm{f}} \\
6,0 \\
6,0 \\
7,0^{\mathrm{f}}\end{array}$ \\
\hline Szwecja & $\begin{array}{l}2004 \\
2005 \\
2006 \\
2007 \\
2008 \\
2009 \\
2010 \\
2011 \\
\end{array}$ & $\begin{array}{l}10462,7^{\mathrm{g}} \\
11231,3^{\mathrm{f}} \\
11928,7^{2} \\
11951,6 \\
13496,1^{\mathrm{c}} \\
12461,8 \\
12485,6^{\mathrm{c}} \\
13216,2^{\mathrm{c}, \mathrm{f}}\end{array}$ & $\begin{array}{l}3,62^{\mathrm{g}} \\
3,80^{\mathrm{f}} \\
3,68 \\
3,40 \\
3,70^{\mathrm{c}} \\
3,60 \\
3,39^{\mathrm{c}} \\
3,37^{\mathrm{c}, \mathrm{f}}\end{array}$ & $\begin{array}{c}\cdot \dot{ } \\
65,7^{\mathrm{f}} \\
\dot{6}, 3 \\
\dot{6}, 3 \\
58,8 \\
\dot{58,2^{\mathrm{c}, \mathrm{f}}}\end{array}$ & $\begin{array}{l}23,2^{\mathrm{f}} \\
\dot{2}, 9 \\
\dot{2}, 5 \\
\dot{2}, 5^{\mathrm{c}, \mathrm{f}}\end{array}$ & $\begin{array}{l}3,4^{\mathrm{f}} \\
\dot{3,1} \\
\dot{3,2} \\
\dot{3,2^{\mathrm{c}, \mathrm{f}}}\end{array}$ & $\begin{array}{c}\cdot 7^{\mathrm{f}} \\
\cdot \\
9,7 \\
\dot{10,4} \\
\cdot 9^{\mathrm{c}, \mathrm{f}}\end{array}$ \\
\hline Węgry & $\begin{array}{l}2004 \\
2005 \\
2006 \\
2007 \\
2008 \\
2009 \\
2010 \\
2011 \\
\end{array}$ & $\begin{array}{l}1439,2^{\mathrm{f}} \\
1616,7 \\
1849,8 \\
1870,7 \\
2058,2 \\
2369,5 \\
2404,6 \\
2581,9 \\
\end{array}$ & $\begin{array}{l}0,88^{\mathrm{f}} \\
0,94 \\
1,01 \\
0,98 \\
1,00 \\
1,17 \\
1,17 \\
1,21 \\
\end{array}$ & $\begin{array}{l}37,1^{\text {f }} \\
39,4 \\
43,4 \\
43,9 \\
48,3 \\
46,4 \\
47,4 \\
47,5 \\
\end{array}$ & $\begin{array}{l}51,8^{\text {f }} \\
49,4 \\
44,8 \\
44,4 \\
41,8 \\
42,0 \\
39,3 \\
38,1 \\
\end{array}$ & $\begin{array}{l}0,8^{\mathrm{f}} \\
0,3 \\
0,6 \\
0,6 \\
0,6 \\
0,7 \\
0,9 \\
0,1 \\
\end{array}$ & $\begin{array}{r}10,4^{\mathrm{f}} \\
10,7 \\
11,3 \\
11,1 \\
9,3 \\
10,9 \\
12,4 \\
13,5 \\
\end{array}$ \\
\hline $\begin{array}{l}\text { Wielka } \\
\text { Brytania }\end{array}$ & $\begin{array}{l}2004 \\
2005 \\
2006 \\
2007 \\
2008 \\
2009 \\
2010 \\
2011 \\
\end{array}$ & $\begin{array}{l}32056,9 \\
33413,4 \\
36982,0 \\
38731,5 \\
39396,9^{\mathrm{c}} \\
39213,2^{\mathrm{c}} \\
39505,8^{\mathrm{c}} \\
39627,1^{\mathrm{e}}\end{array}$ & $\begin{array}{l}1,71 \\
1,76 \\
1,74 \\
1,77 \\
1,78^{\mathrm{c}} \\
1,84^{\mathrm{c}} \\
1,80^{\mathrm{c}} \\
1,77^{\mathrm{e}} \\
\end{array}$ & $\begin{array}{l}44,1 \\
42,1 \\
45,2 \\
46,0 \\
45,4^{\mathrm{c}} \\
44,5^{\mathrm{c}} \\
44,0^{\mathrm{c}} \\
44,6^{\mathrm{e}}\end{array}$ & $\begin{array}{l}32,9 \\
32,7^{-} \\
31,9 \\
30,9 \\
30,7^{\mathrm{c}} \\
32,6^{\mathrm{c}} \\
32,3^{\mathrm{c}} \\
32,2^{\mathrm{e}}\end{array}$ & $\begin{array}{l}5,9 \\
5,9 \\
5,9 \\
5,8 \\
6,2^{\mathrm{c}} \\
6,3^{\mathrm{c}} \\
6,0^{\mathrm{c}} \\
6,2^{\mathrm{e}}\end{array}$ & $\begin{array}{l}17,1 \\
19,3 \\
17,0 \\
17,3 \\
17,7^{\mathrm{c}} \\
16,6^{\mathrm{c}} \\
17,6^{\mathrm{c}} \\
17,0^{\mathrm{e}}\end{array}$ \\
\hline Włochy & $\begin{array}{l}2004 \\
2005 \\
2006 \\
2007 \\
2008 \\
2009 \\
2010 \\
2011 \\
\end{array}$ & $\begin{array}{l}17500,7 \\
17827,0 \\
20172,4 \\
22315,3 \\
24076,1 \\
24511,5 \\
24540,5 \\
24812,1^{\mathrm{e}}\end{array}$ & $\begin{array}{l}1,10 \\
1,09 \\
1,13 \\
1,17 \\
1,21 \\
1,26 \\
1,26 \\
1,25^{\mathrm{e}}\end{array}$ & $\begin{array}{c}\cdot \\
39,7 \\
40,4 \\
42,0 \\
45,9 \\
44,2 \\
44,7 \\
.\end{array}$ & $\begin{array}{c}\cdot \\
50,7 \\
47,0 \\
44,3 \\
42,0 \\
42,1 \\
41,6\end{array}$ & $\begin{array}{l}\cdot \\
1,7 \\
4,3 \\
4,2 \\
4,1 \\
4,3 \\
4,0 \\
.\end{array}$ & $\begin{array}{l}\cdot \\
8,0 \\
8,3 \\
9,5 \\
7,9 \\
9,4 \\
9,8 \\
.\end{array}$ \\
\hline
\end{tabular}

Wyjaśnienia: ${ }^{a}$ wydatki wyrażone są w mln parytetu siły nabywczej dol. USA (w cenach rynkowych); ${ }^{\text {b }}$ suma udziałów procentowych poszczególnych podmiotów nie jest zawsze równa $100 ;{ }^{c}$ są to narodowe szacunki albo prognozy; ${ }^{\mathrm{d}}$ obejmuje także inne sektory; ${ }^{\mathrm{e}}$ dane prowizoryczne; ${ }^{\mathrm{f}}$ informacje nie w pełni porównywalne $\mathrm{z}$ danymi statystycznymi za poprzednie lata; ${ }^{\mathrm{g}}$ dane zaniżone.

Źródła: OECD (2008), Main and Science and Technology Indicators, vol. 2008/2, Paris 2008, s. 18, 24 i 25; OECD (2013), Main and Science and Technology Indicators, vol. 2013/1, Paris 2013, s. 20, 21, 32-35.

Istniejąca struktura finansowania $\mathrm{B}+\mathrm{R}$ nie wywarła w Polsce pozytywnego wpływu na układ sektorów instytucjonalnych nauki. Prace badawcze i rozwojowe nie były prowadzone w przeważającej mierze w gospodarce, co było zjawiskiem negatywnym. Koncentrowały się one w trzech sektorach, a mianowicie w szkołach wyższych, rządowych instytucjach badawczych i w firmach. Szkoły wyższe obejmowały tak uczelnie państwowe jak prywatne. $\mathrm{W}$ tych ostatnich rzadko realizowano $\mathrm{B}+\mathrm{R}$. Do rządowych 
instytucji badawczych zaliczano głównie jednostki badawczo-rozwojowe (od października 2010 r. - instytuty badawcze) oraz instytuty Polskiej Akademii Nauk.

W większości starych państw członkowskich gospodarka była najważniejszym sektorem instytucjonalnym nauki, przy czym pozycja jego była szczególnie silna w takich krajach jak Austria, Belgia, Finlandia, Francja, Holandia, Irlandia, Luksemburg, RFN i Szwecja. Sektor ten wyróżniał się również w Republice Czeskiej, Rumunii, Słowenii i na Węgrzech (patrz tabela 3).

Warto tu podkreślić, że Polska należała do krajów o stosunkowo niskim udziale przemysłów wysokiej technologii w konsumpcji wydatków badawczo-rozwojowych gospodarki. Siegał on w 2004 r. 30,5\%, podczas np. w Finlandii, W. Brytanii, Szwecji i Danii - odpowiednio 66,4\%, 62,5\%, 58,5\% i 57,9\% (European Commission, s. 68). W latach następnych udział ten był w Polsce - jak się wydaje - nadal stosunkowo mały. Dla jego zasadniczego zwiększenia niezbędne byłoby bowiem poważne zintensyfikowanie popierania przez firmy $\mathrm{B}+\mathrm{R}$, a ono nie nastapiło.

Ujemny wpływ na pozycję Polski w UE w zakresie prac badawczych i rozwojowych wywierały także wąski zakres współpracy w dziedzinie $\mathrm{B}+\mathrm{R}$ między przedsiębiorstwami a uczelniami oraz zbyt małe uczestnictwo strony polskiej w unijnych programach ramowych w zakresie badań, rozwoju technologicznego i demonstracji. Jedynie niekiedy szkoły wyższe pomagały firmom w prowadzeniu badań nad innowacyjnymi projektami. Typowe dla wzajemnej współpracy było organizowanie staży i praktyk dla studentów (Uczelnie zaczynaja wspólpracować z firmami, s. 1; Prezentacja form wspótpracy..., s. 1).

Udział w przeprowadzaniu programów ramowych należał do najważniejszych elementów międzynarodowej współpracy badawczo-rozwojowej Polski. W okresie realizacji 7 programu (po 337 zakończonych konkursach) strona polska wnioskowała o ok. 2,5 mld euro, a uzyskała jedynie 286,5 mln euro. Współczynnik sukcesu wynosił jedynie $17 \%$, podczas gdy w Unii - średnio $20 \%$. Znacznie gorzej przedstawiała się sytuacja w przypadku porównania liczby zgłoszonych wniosków i otrzymanych środków $\mathrm{z}$ liczbą osób zatrudnionych $\mathrm{w}$ dziedzinie $\mathrm{B}+\mathrm{R}$. Polska zajmowała pod względem wielkości tych wskaźników przedostatnie miejsce wśród krajów członkowskich UE (Wilkin, 2013, s. 58).

Mały udział polskich naukowców w realizacji programów ramowych wynikał z kilku uwarunkowań. Do tych uwarunkowań należała praca na kilku etatach, czego konsekwencją było zbyt duże obciążenie działalnością dydaktyczną. Jednocześnie duża część pracowników naukowych uczestniczyła w realizacji programów wspólnotowych, prowadząc szkolenia i pełniąc funkcje eksperckie. Te obciążenia wywierały też niewaţpliwy negatywny wpływ na efektywność prowadzonych w Polsce prac badawczych i rozwojowych.

Większość polskich uczelni nie była właściwie przygotowana (pod względem organizacyjnym) do starań o projekty unijne. Nie dysponowała pracownikami administracyjnymi, którzy pomagaliby w opracowaniu, a następnie w realizacji projektów.

Bardzo istotne znaczenie miał fakt, że w Polsce było mało jednostek badawczych, które prowadziłyby nowatorskie badania o charakterze interdyscyplinarnym czy byłyby centrami zaawansowanych badań naukowych. Związane to było w pierwszym rzędzie z nikłą intensywnością badawczo-rozwojową. 
Starania o projekty unijne komplikowały trudności z uzyskaniem wkładu własnego oraz występujące w polskich instytucjach naukowych niełatwe warunki lokalowe i finansowe (Wilkin, 2013, s. 59-61).

Tabela 3

Udzial poszczególnych sektorów instytucjonalnych nauki w Polsce i innych krajach UE w realizacji prac badawczych i rozwojowych

\begin{tabular}{|c|c|c|c|c|c|c|c|c|c|}
\hline \multirow{3}{*}{ Kraj } & \multirow{3}{*}{ Rok } & \multicolumn{8}{|c|}{ Udział sektorów nauki } \\
\hline & & \multicolumn{4}{|c|}{$\begin{array}{c}\text { w konsumpcji ogólnych wydatków } \\
\text { na } \mathrm{B}+\mathrm{R}(\%)^{\mathrm{a}} \\
\end{array}$} & \multicolumn{4}{|c|}{$\begin{array}{c}\text { w ogólnej liczbie kadr } \\
\text { badawczo-rozwojowych }(\%)^{\mathrm{a}}\end{array}$} \\
\hline & & $\begin{array}{l}\text { gospo- } \\
\text { darka }\end{array}$ & $\begin{array}{l}\text { szkoły } \\
\text { wyższe }\end{array}$ & $\begin{array}{c}\text { instytucje } \\
\text { badawcze } \\
\text { rząd. }\end{array}$ & $\begin{array}{c}\text { instytucje } \\
\text { naukowe } \\
\text { niekom. }\end{array}$ & $\begin{array}{l}\text { gospo- } \\
\text { darka }\end{array}$ & $\begin{array}{l}\text { szkoły } \\
\text { wyższe }\end{array}$ & $\begin{array}{c}\text { instytucje } \\
\text { badawcze } \\
\text { rząd. }\end{array}$ & $\begin{array}{l}\text { instytucje } \\
\text { naukowe } \\
\text { niekom. }\end{array}$ \\
\hline 1 & 2 & 3 & 4 & 5 & 6 & 7 & 8 & 9 & 10 \\
\hline Austria & $\begin{array}{l}2004 \\
2005 \\
2006 \\
2007 \\
2008 \\
2009 \\
2010 \\
2011 \\
\end{array}$ & $\begin{array}{l}67,7 \\
69,6^{\mathrm{b}} \\
70,4 \\
70,6^{\mathrm{b}} \\
69,3^{\mathrm{b}} \\
68,1^{\mathrm{b}} \\
68,1^{\mathrm{b}} \\
68,1^{\mathrm{b}, \mathrm{d}} \\
\end{array}$ & $\begin{array}{l}26,7 \\
24,8^{\mathrm{b}} \\
24,1 \\
23,8^{\circ} \\
25,0^{\mathrm{b}} \\
26,1^{\mathrm{b}} \\
26,1^{\mathrm{b}} \\
26,1^{\mathrm{b}, \mathrm{d}} \\
\end{array}$ & $\begin{array}{l}5,1 \\
5,2^{\mathrm{b}} \\
5,2 \\
5,3 \\
5,3^{\mathrm{b}} \\
5,3^{\circ} \\
5,3^{\mathrm{b}} \\
5,3^{\mathrm{b}, \mathrm{d}}\end{array}$ & $\begin{array}{l}0,4 \\
0,3^{\mathrm{b}} \\
0,3 \\
0,3 \\
0,4^{\mathrm{b}} \\
0,5^{\mathrm{c}} \\
0,5^{\mathrm{b}} \\
0,5^{\mathrm{b}, \mathrm{d}}\end{array}$ & $\begin{array}{l}67,9 \\
68,8^{\mathrm{b}} \\
69,1 \\
69,5 \\
69,5^{\mathrm{b}} \\
67,9^{-} \\
67,9^{\mathrm{b}} \\
67,9^{\mathrm{b}, \mathrm{d}} \\
\end{array}$ & $\begin{array}{l}26,8 \\
26,0^{b} \\
25,7 \\
25,6 \\
25,6^{b} \\
26,7 \\
26,7 \\
26,7^{\text {b,d }}\end{array}$ & $\begin{array}{l}4,7 \\
4,9^{\mathrm{b}} \\
4,9 \\
4,7 \\
4,7^{\mathrm{b}} \\
4,7 \\
4,8 \\
4,8^{\mathrm{b}, \mathrm{d}} \\
\end{array}$ & $\begin{array}{l}0,5 \\
0,3^{\mathrm{b}} \\
0,3 \\
0,2^{\mathrm{b}} \\
0,2^{\mathrm{b}} \\
0,7 \\
0,6 \\
0,6^{\mathrm{b}, \mathrm{d}}\end{array}$ \\
\hline Belgia & $\begin{array}{l}2004 \\
2005 \\
2006 \\
2007 \\
2008 \\
2009 \\
2010 \\
2011 \\
\end{array}$ & $\begin{array}{l}69,1 \\
68,0 \\
69,3 \\
69,5 \\
68,3 \\
66,3 \\
66,2 \\
67,1 \\
\end{array}$ & $\begin{array}{l}21,8 \\
22,3 \\
21,3 \\
21,1 \\
21,8 \\
23,8 \\
23,6 \\
22,9 \\
\end{array}$ & $\begin{array}{l}7,7 \\
8,4 \\
8,0 \\
8,1 \\
8,9 \\
8,9 \\
9,2 \\
9,0 \\
\end{array}$ & $\begin{array}{l}1,4 \\
1,3 \\
1,4 \\
1,3 \\
1,0 \\
1,0 \\
1,0 \\
1,0 \\
\end{array}$ & $\begin{array}{l}58,8 \\
59,1 \\
58,8 \\
58,7 \\
56,3 \\
55,2 \\
52,9 \\
52,8^{\text {d }}\end{array}$ & $\begin{array}{l}33,4 \\
33,2 \\
33,6 \\
33,7 \\
35,4 \\
36,2 \\
38,2 \\
38,2^{\text {d }}\end{array}$ & $\begin{array}{l}6,7 \\
6,7 \\
6,6 \\
6,6 \\
7,4 \\
7,8 \\
7,9 \\
8,0^{\text {d }} \\
\end{array}$ & $\begin{array}{l}1,1 \\
1,0 \\
1,0 \\
1,0 \\
0,9 \\
0,8 \\
1,0 \\
1,0\end{array}$ \\
\hline Czechy & $\begin{array}{l}2004 \\
2005 \\
2006 \\
2007 \\
2008 \\
2009 \\
2010 \\
2011 \\
\end{array}$ & $\begin{array}{l}63,7 \\
64,5 \\
65,1 \\
61,9 \\
61,9 \\
60,0 \\
62,0 \\
60,3 \\
\end{array}$ & $\begin{array}{l}14,8 \\
16,4 \\
15,9 \\
16,9 \\
16,8 \\
18,1 \\
18,0 \\
21,6 \\
\end{array}$ & $\begin{array}{l}21,2 \\
18,7 \\
18,7 \\
20,8 \\
20,9 \\
21,4 \\
19,4 \\
17,5 \\
\end{array}$ & $\begin{array}{l}0,4 \\
0,5 \\
0,4 \\
0,4 \\
0,4 \\
0,5 \\
0,5 \\
0,5 \\
\end{array}$ & $\begin{array}{l}52,4 \\
51,1 \\
49,7 \\
51,3 \\
51,3 \\
50,8 \\
51,6 \\
53,0 \\
\end{array}$ & $\begin{array}{l}21,2 \\
24,9 \\
26,8 \\
25,4 \\
25,9 \\
26,8 \\
26,9 \\
26,4 \\
\end{array}$ & $\begin{array}{l}25,8 \\
23,6 \\
23,2 \\
23,1 \\
22,4 \\
21,9 \\
20,9 \\
20,0 \\
\end{array}$ & $\begin{array}{l}0,6 \\
0,4 \\
0,3 \\
0,2 \\
0,4 \\
0,5 \\
0,6 \\
0,6 \\
\end{array}$ \\
\hline Dania & $\begin{array}{l}2004 \\
2005 \\
2006 \\
2007 \\
2008 \\
2009 \\
2010 \\
2011 \\
\end{array}$ & $\begin{array}{l}68,0 \\
68,3 \\
66,9 \\
69,9^{\text {c }} \\
69,9 \\
69,8 \\
68,2 \\
67,6^{\text {b,d }} \\
\end{array}$ & $\begin{array}{l}24,4 \\
24,6 \\
25,9 \\
26,4^{\mathrm{c}} \\
27,2 \\
27,7 \\
29,3 \\
29,8^{\mathrm{b}, \mathrm{d}} \\
\end{array}$ & $\begin{array}{l}6,9 \\
6,5 \\
6,6 \\
3,2^{\mathrm{c}} \\
2,6 \\
2,1 \\
2,1 \\
2,2^{\mathrm{b}, \mathrm{d}} \\
\end{array}$ & $\begin{array}{l}0,7 \\
0,7 \\
0,6 \\
0,5^{\mathrm{c}} \\
0,3 \\
0,4 \\
0,4 \\
0,4^{\mathrm{b}, \mathrm{d}}\end{array}$ & $\begin{array}{l}65,7 \\
65,2 \\
65,2 \\
66,5^{\mathrm{c}} \\
70,1^{\mathrm{b}} \\
66,8 \\
64,7 \\
65,1^{\text {b,d }}\end{array}$ & $\begin{array}{l}26,1 \\
26,6 \\
26,9^{\text {c }} \\
29,3^{\text {c }} \\
26,9^{b} \\
30,1 \\
32,2 \\
31,7^{\text {b,d }}\end{array}$ & $\begin{array}{l}7,6 \\
7,4 \\
7,3 \\
3,7^{\mathrm{c}} \\
2,6^{\mathrm{b}} \\
2,6 \\
2,6 \\
2,6^{\mathrm{b}, \mathrm{d}} \\
\end{array}$ & $\begin{array}{l}0,6 \\
0,8 \\
0,6 \\
0,5^{\mathrm{c}} \\
0,5^{\mathrm{b}} \\
0,5 \\
0,5 \\
0,6^{\mathrm{b}, \mathrm{d}}\end{array}$ \\
\hline Estonia & $\begin{array}{l}2004 \\
2005 \\
2006 \\
2007 \\
2008 \\
2009 \\
2010 \\
2011\end{array}$ & $\begin{array}{c}\cdot \\
44,4 \\
47,2 \\
43,2 \\
44,7 \\
50,2 \\
63,2\end{array}$ & $\begin{array}{c}\cdot \\
40,6 \\
41,8 \\
42,9 \\
42,2 \\
38,0 \\
27,8\end{array}$ & $\begin{array}{r}\cdot \\
13,1 \\
8,7 \\
11,8 \\
11,0 \\
10,6 \\
8,1\end{array}$ & $\begin{array}{c}\cdot \\
\cdot \\
1,8 \\
2,4 \\
2,1 \\
2,2 \\
1,2 \\
0,9\end{array}$ & $\begin{array}{c}\cdot \\
34,4 \\
33,8 \\
36,3 \\
35,4 \\
37,0 \\
37,1\end{array}$ & $\begin{array}{c}\cdot \\
48,3 \\
48,1 \\
47,0 \\
49,5 \\
46,7 \\
47,8\end{array}$ & $\begin{array}{c}\cdot \\
\dot{15}, 1 \\
15,6 \\
14,7 \\
13,2 \\
14,6 \\
13,6\end{array}$ & $\begin{array}{l}\cdot \\
2,2 \\
2,5 \\
2,0 \\
1,9 \\
1,7 \\
1,5\end{array}$ \\
\hline
\end{tabular}




\begin{tabular}{|c|c|c|c|c|c|c|c|c|c|}
\hline 1 & 2 & 3 & 4 & 5 & 6 & 7 & 8 & 9 & 10 \\
\hline Finlandia & $\begin{array}{l}2004 \\
2005 \\
2006 \\
2007 \\
2008 \\
2009 \\
2010 \\
2011 \\
\end{array}$ & $\begin{array}{l}70,1 \\
70,8 \\
71,3 \\
72,3 \\
74,3 \\
71,4 \\
69,6 \\
70,5 \\
\end{array}$ & $\begin{array}{l}19,8 \\
19,0 \\
18,7 \\
18,7 \\
17,2 \\
18,9 \\
20,4 \\
20,0 \\
\end{array}$ & $\begin{array}{l}9,5 \\
9,6 \\
9,3 \\
8,5 \\
8,0 \\
9,1 \\
9,2 \\
8,8\end{array}$ & $\begin{array}{l}0,6 \\
0,6 \\
0,6 \\
0,6 \\
0,5 \\
0,6 \\
0,7 \\
0,7\end{array}$ & $\begin{array}{l}56,0 \\
55,9 \\
56,6 \\
56,8 \\
58,4 \\
57,5 \\
54,7 \\
57,2^{\mathrm{c}}\end{array}$ & $\begin{array}{c}30,6 \\
30,4 \\
29,8 \\
29,3 \\
28,2 \\
29,4 \\
32,1 \\
29,1^{\text {c }}\end{array}$ & $\begin{array}{c}12,6 \\
12,9 \\
12,7 \\
13,0 \\
12,6 \\
12,1 \\
12,2 \\
12,6^{\mathrm{C}} \\
\end{array}$ & $\begin{array}{l}0,8 \\
0,8 \\
0,9 \\
0,9 \\
0,8 \\
1,0 \\
1,0 \\
1,1^{\text {c }}\end{array}$ \\
\hline Francja & $\begin{array}{l}2004 \\
2005 \\
2006 \\
2007 \\
2008 \\
2009 \\
2010 \\
2011 \\
\end{array}$ & $\begin{array}{l}63,1 \\
62,1^{1} \\
63,1^{\mathrm{c}} \\
63,0 \\
62,7 \\
61,7 \\
63,2^{\mathrm{c}} \\
63,4 \\
\end{array}$ & $\begin{array}{l}18,6 \\
18,8 \\
19,2 \\
19,5 \\
20,0 \\
20,8 \\
21,6^{c} \\
21,2\end{array}$ & $\begin{array}{l}17,0 \\
17,8 \\
16,5 \\
16,4 \\
16,0 \\
16,3 \\
14,0^{\mathrm{c}} \\
14,1 \\
\end{array}$ & $\begin{array}{l}1,3 \\
1,3 \\
1,2 \\
1,2 \\
1,2 \\
1,2 \\
1,3^{\mathrm{c}} \\
1,2 \\
\end{array}$ & $\begin{array}{l}57,0 \\
55,2 \\
56,8^{\mathrm{c}} \\
57,5 \\
57,5^{\mathrm{e}} \\
57,9^{\mathrm{e}} \\
58,7^{\mathrm{c}} \\
. \\
\end{array}$ & $\begin{array}{l}27,6 \\
28,0 \\
27,6 \\
27,3 \\
27,4 \\
26,9 \\
27,1\end{array}$ & $\begin{array}{l}13,7 \\
14,1 \\
13,9^{\mathrm{e}} \\
13,6^{\mathrm{e}} \\
13,6^{\mathrm{e}} \\
13,6^{\mathrm{e}} \\
12,7\end{array}$ & $\begin{array}{c}1,7 \\
2,7 \\
1,7 \\
1.6 \\
1,5 \\
1,6 \\
1,5 \\
. \\
\end{array}$ \\
\hline Grecja & $\begin{array}{l}2004 \\
2005 \\
2006 \\
2007 \\
2008 \\
2009 \\
2010 \\
2011 \\
\end{array}$ & $\begin{array}{c}31,1 \\
31,0 \\
30,0^{\mathrm{b}} \\
28,6^{\mathrm{b}} \\
\cdot \\
. \\
. \\
.\end{array}$ & $\begin{array}{c}48,2 \\
47,5 \\
47,8^{\mathrm{b}} \\
49,2^{\mathrm{b}} \\
\cdot \\
. \\
. \\
.\end{array}$ & $\begin{array}{c}19,8 \\
20,3 \\
20,8^{\mathrm{b}} \\
20,9^{\mathrm{b}} \\
. \\
. \\
. \\
.\end{array}$ & $\begin{array}{l}0,9 \\
0,9 \\
1,3^{\mathrm{b}} \\
1,3^{\mathrm{b}} \\
\cdot \\
. \\
. \\
.\end{array}$ & $\begin{array}{c}34,7 \\
32,4^{\mathrm{b}} \\
32,5^{\mathrm{b}} \\
. \\
. \\
. \\
.\end{array}$ & $\begin{array}{c}51,8 \\
53,9^{\mathrm{b}} \\
53,9^{\mathrm{b}} \\
. \\
. \\
. \\
.\end{array}$ & $\begin{array}{c}12,9 \\
13,0^{\mathrm{b}} \\
12,9^{\mathrm{b}} \\
\cdot \\
. \\
.\end{array}$ & $\begin{array}{l}0,6 \\
0,7^{\mathrm{b}} \\
0,7^{\mathrm{b}} \\
\cdot \\
\cdot \\
\cdot \\
\end{array}$ \\
\hline Hiszpania & $\begin{array}{l}2004 \\
2005 \\
2006 \\
2007 \\
2008 \\
2009 \\
2010 \\
2011\end{array}$ & $\begin{array}{l}54,4 \\
53,8 \\
55,5 \\
55,9 \\
54,9^{c} \\
51,9 \\
51,5 \\
52,1\end{array}$ & $\begin{array}{l}29,5 \\
29,0 \\
27,6 \\
26,4 \\
26,7^{\mathrm{c}} \\
27,8 \\
28,3 \\
28,2\end{array}$ & $\begin{array}{l}16,0 \\
17,0 \\
16,7 \\
17,6 \\
18,2^{\mathrm{c}} \\
20,1 \\
20,1 \\
19,5\end{array}$ & $\begin{array}{l}0,1 \\
0,1 \\
0,2 \\
0,2 \\
0,2^{\mathrm{c}} \\
0,2 \\
0,2 \\
0,2\end{array}$ & $\begin{array}{l}43,9 \\
43,1 \\
43,9 \\
43,5 \\
44,1^{c} \\
42,4 \\
41,5 \\
41,8\end{array}$ & $\begin{array}{l}39,1 \\
38,3 \\
37,6 \\
37,3 \\
36,5 \\
36,7 \\
37,5 \\
37,6\end{array}$ & $\begin{array}{l}16,8 \\
18,3 \\
18,3 \\
18,8 \\
19,1 \\
20,5 \\
20,7 \\
20,4\end{array}$ & $\begin{array}{l}0,2 \\
0,3 \\
0,2 \\
0,4 \\
0,3 \\
0,4 \\
0,3 \\
0,2\end{array}$ \\
\hline Holandia & $\begin{array}{l}2004 \\
2005 \\
2006 \\
2007 \\
2008 \\
2009 \\
2010 \\
2011 \\
\end{array}$ & $\begin{array}{c}57,9 \\
58,5 \\
53,9 \\
53,1 \\
50,1 \\
47,1 \\
47,9 \\
.\end{array}$ & $\begin{array}{c}27,8 \\
27,8 \\
33,8 \\
34,7 \\
37,9 \\
40,2 \\
40,4 \\
. \\
\end{array}$ & $\begin{array}{c}14,3 \\
13,8 \\
12,4^{\mathrm{f}} \\
12,2^{\mathrm{f}} \\
12,0^{\mathrm{f}} \\
12,7^{\mathrm{f}} \\
11,7^{\mathrm{f}} \\
.\end{array}$ & $\begin{array}{l}\cdot \\
\cdot \\
\cdot \\
\cdot \\
\cdot \\
\cdot \\
\cdot \\
.\end{array}$ & $\begin{array}{c}54,6^{\mathrm{d}} \\
54,2^{\mathrm{d}} \\
54,0 \\
52,5 \\
51,4 \\
48,2 \\
53,8 \\
.\end{array}$ & $\begin{array}{c}30,7^{\mathrm{d}} \\
31,7^{\mathrm{d}} \\
32,9 \\
34,5 \\
35,6 \\
38,8 \\
34,8 \\
.\end{array}$ & $\begin{array}{l}14,8^{\mathrm{d}} \\
14,2^{\mathrm{d}} \\
13,0^{\mathrm{f}} \\
12,9^{\mathrm{f}} \\
13,0^{\mathrm{f}} \\
13,0^{\mathrm{f}} \\
11,4^{\mathrm{f}}\end{array}$ & $\begin{array}{l}\cdot \\
\dot{0} \\
0,1 \\
0,1 \\
\cdot \\
\cdot \\
\cdot \\
\cdot\end{array}$ \\
\hline Irlandia & $\begin{array}{l}2004 \\
2005 \\
2006 \\
2007 \\
2008 \\
2009 \\
2010 \\
2011 \\
\end{array}$ & $\begin{array}{l}65,7 \\
65,5 \\
66,1 \\
65,9 \\
64,7 \\
68,3 \\
68,7^{\mathrm{b}} \\
69,0^{\mathrm{b}} \\
\end{array}$ & $\begin{array}{l}26,7 \\
27,1 \\
27,1 \\
27,1 \\
28,8 \\
26,6 \\
26,5^{\mathrm{b}} \\
26,1^{\mathrm{b}}\end{array}$ & $\begin{array}{l}7,5 \\
7,4 \\
6,8 \\
6,9 \\
6,5 \\
5,0 \\
4,8^{b} \\
4,9^{b}\end{array}$ & $\begin{array}{l}. \\
. \\
. \\
. \\
. \\
.\end{array}$ & $\begin{array}{c}\cdot \\
61,0 \\
60,3 \\
58,7 \\
60,7 \\
61,8^{\mathrm{b}} \\
65,5^{\mathrm{b}} \\
\end{array}$ & $\begin{array}{c}. \\
32,2 \\
33,0 \\
35,7 \\
34,0 \\
32,9^{\mathrm{b}} \\
29,7^{\mathrm{b}}\end{array}$ & $\begin{array}{l}6,8 \\
6,6 \\
5,6 \\
5,3 \\
5,2^{\mathrm{b}} \\
4,8^{\mathrm{b}} \\
\end{array}$ & $\begin{array}{l}. \\
. \mathrm{g} \\
0,1^{\mathrm{g}} \\
\mathrm{g}^{\mathrm{g}} \\
\mathrm{g} \\
0,1^{\mathrm{b}, \mathrm{g}} \\
. \mathrm{g}\end{array}$ \\
\hline $\begin{array}{l}\text { Luksem- } \\
\text { burg }\end{array}$ & $\begin{array}{l}2004 \\
2005 \\
2006 \\
2007 \\
2008 \\
2009 \\
2010 \\
2011\end{array}$ & $\begin{array}{l}87,8 \\
86,4 \\
86,1 \\
83,7^{\mathrm{b}} \\
77,9 \\
75,9 \\
67,6 \\
68,5^{\mathrm{b}}\end{array}$ & $\begin{array}{r}1,2 \\
1,5 \\
2,1 \\
3,0^{\mathrm{b}} \\
6,1 \\
8,0 \\
12,7 \\
12,4^{\mathrm{b}}\end{array}$ & $\begin{array}{l}11,0 \\
12,1 \\
11,8 \\
13,4^{b} \\
16,0^{b} \\
16,1^{\mathrm{c}} \\
19,7 \\
19,2^{\mathrm{b}}\end{array}$ & $\begin{array}{l}. \\
. \\
. \\
. \\
.\end{array}$ & $\begin{array}{l}84,7 \\
83,4 \\
81,1 \\
79,7^{\mathrm{b}} \\
75,6 \\
70,4 \\
67,9 \\
67,9^{\mathrm{b}}\end{array}$ & $\begin{array}{r}3,5 \\
3,8 \\
4,4 \\
4,5^{\mathrm{b}} \\
7,0 \\
10,3 \\
11,9 \\
11,9^{\mathrm{b}}\end{array}$ & $\begin{array}{l}11,9 \\
12,8 \\
14,5 \\
15,7^{\mathrm{b}} \\
17,4 \\
19,3 \\
20,2 \\
20,2^{\mathrm{b}}\end{array}$ & $\begin{array}{l}\mathrm{g} \\
\mathrm{g} \\
\mathrm{g} \\
0,1^{\mathrm{b}, \mathrm{g}} \\
\mathrm{g} \\
\mathrm{g} \\
\mathrm{g} \\
\mathrm{g} \\
\mathrm{g}\end{array}$ \\
\hline
\end{tabular}




\begin{tabular}{|c|c|c|c|c|c|c|c|c|c|}
\hline 1 & 2 & 3 & 4 & 5 & 6 & 7 & 8 & 9 & 10 \\
\hline Polska & $\begin{array}{l}2004 \\
2005 \\
2006 \\
2007 \\
2008 \\
2009 \\
2010 \\
2011 \\
\end{array}$ & $\begin{array}{l}28,7 \\
31,8 \\
31,5 \\
30,4 \\
30,9 \\
28,5 \\
26,6 \\
30,1 \\
\end{array}$ & $\begin{array}{l}32,0 \\
31,6 \\
31,0 \\
33,9 \\
33,6 \\
37,1 \\
37,2 \\
35,1 \\
\end{array}$ & $\begin{array}{l}39,0 \\
36,4 \\
37,0 \\
35,4 \\
35,3 \\
34,3 \\
35,9 \\
34,5 \\
\end{array}$ & $\begin{array}{l}0,4 \\
0,3 \\
0,4 \\
0,3 \\
0,1 \\
0,1 \\
0,3 \\
0,2 \\
\end{array}$ & $\begin{array}{l}16,6 \\
18,2 \\
19,3 \\
20,0 \\
17,2 \\
18,6 \\
22,5 \\
22,9 \\
\end{array}$ & $\begin{array}{l}58,3 \\
58,3 \\
56,6 \\
56,7 \\
58,4 \\
56,3 \\
52,6 \\
51,8 \\
\end{array}$ & $\begin{array}{l}25,2 \\
23,3 \\
24,1 \\
23,2 \\
24,5 \\
25,0 \\
24,6 \\
25,1 \\
\end{array}$ & $\begin{array}{l}{ }^{\mathrm{g}} \\
\mathrm{g} \\
\mathrm{g}^{\mathrm{g}} \\
\mathrm{g} \\
\mathrm{g} \\
\mathrm{g}_{\mathrm{g}} \\
0,3^{\mathrm{g}} \\
0,2^{\mathrm{g}}\end{array}$ \\
\hline $\begin{array}{l}\text { Portuga- } \\
\text { lia }\end{array}$ & $\begin{array}{l}2004 \\
2005 \\
2006 \\
2007 \\
2008 \\
2009 \\
2010 \\
2011 \\
\end{array}$ & $\begin{array}{l}36,0^{\mathrm{b}} \\
38,5^{\mathrm{b}} \\
46,4^{\mathrm{b}} \\
51,2^{1} \\
50,1^{\mathrm{c}} \\
47,4^{-} \\
46,1^{\mathrm{d}} \\
45,9^{\mathrm{m}}\end{array}$ & $\begin{array}{l}36,8 \\
35,4^{\mathrm{b}} \\
31,9^{\mathrm{b}} \\
29,8^{-} \\
34,5^{\mathrm{c}} \\
36,4 \\
36,7^{\mathrm{d}} \\
38,3^{\mathrm{d}}\end{array}$ & $\begin{array}{c}15,7 \\
14,6 \\
11,3^{\mathrm{b}} \\
9,4 \\
7,3^{\mathrm{c}} \\
7,3 \\
7,1 \\
7,5^{\mathrm{d}} \\
\end{array}$ & $\begin{array}{c}11,5^{\mathrm{b}} \\
11,5 \\
10,4^{\mathrm{b}} \\
9,7^{\mathrm{c}} \\
8,1^{\mathrm{c}} \\
8,8 \\
10,1 \\
8,3^{\mathrm{d}}\end{array}$ & $\begin{array}{l}23,9^{\mathrm{b}} \\
23,8^{\mathrm{b}} \\
31,0^{\mathrm{b}} \\
36,2^{\mathrm{c}} \\
30,3^{\mathrm{c}} \\
27,1 \\
26,8^{\mathrm{d}} \\
26,7^{\mathrm{d}}\end{array}$ & 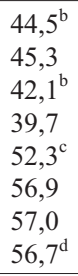 & $\begin{array}{c}18,4^{\mathrm{b}} \\
17,6 \\
14,0 \\
12,8 \\
9,8 \\
7,5 \\
6,4 \\
6,2^{\mathrm{d}} \\
\end{array}$ & $\begin{array}{r}13,2^{\mathrm{b}} \\
13,3 \\
12,9 \\
11,6 \\
7,6 \\
8,5 \\
9,8 \\
10,4 \\
\end{array}$ \\
\hline RFN & $\begin{array}{l}2004 \\
2005 \\
2006 \\
2007 \\
2008 \\
2009 \\
2010 \\
2011 \\
\end{array}$ & $\begin{array}{l}69,7 \\
69,3 \\
70,0 \\
70,0 \\
69,2 \\
67,6 \\
67,1 \\
67,3^{b} \\
\end{array}$ & $\begin{array}{l}16,5 \\
16,5 \\
16,1 \\
16,1 \\
16,7 \\
17,6 \\
18,1 \\
18,0^{b} \\
\end{array}$ & $\begin{array}{l}13,7 \\
14,1 \\
13,9^{\mathrm{f}} \\
13,9^{\mathrm{f}} \\
14,0^{\mathrm{f}} \\
14,8^{\mathrm{f}} \\
14,8^{\mathrm{f}} \\
14,7^{\mathrm{b}, \mathrm{f}}\end{array}$ & $\begin{array}{l}. \\
. \\
. \\
. \\
. \\
. \\
.\end{array}$ & $\begin{array}{l}63,4 \\
64,1 \\
64,0 \\
63,6 \\
63,7 \\
62,2 \\
61,5 \\
61,3^{b} \\
\end{array}$ & $\begin{array}{l}20,4 \\
19,9 \\
20,0^{\mathrm{c}} \\
20,5 \\
20,4 \\
21,6 \\
22,0 \\
22,0^{\mathrm{b}}\end{array}$ & $\begin{array}{l}16,2 \\
16,1 \\
16,1 \\
15,9 \\
15,9 \\
16,2 \\
16,5 \\
16,6 \\
\end{array}$ & $\begin{array}{l}\mathrm{g} \\
\mathrm{g} \\
\mathrm{g} \\
\mathrm{g} \\
\mathrm{g} \\
\mathrm{g} \\
\mathrm{g} \\
\mathrm{g} \\
. \\
\mathrm{g}\end{array}$ \\
\hline Rumunia & $\begin{array}{l}2004 \\
2005 \\
2006 \\
2007 \\
2008 \\
2009 \\
2010 \\
2011 \\
\end{array}$ & $\begin{array}{c}\cdot \\
48,5 \\
41,6 \\
30,0 \\
40,2 \\
38,3 \\
36,0^{\mathrm{c}}\end{array}$ & $\begin{array}{c}\cdot \\
17,7 \\
24,1 \\
28,9 \\
24,7 \\
24,5 \\
22,9^{c}\end{array}$ & $\begin{array}{c}\cdot \\
32,3 \\
33,9 \\
41,0 \\
34,9 \\
36,8 \\
40,7^{\mathrm{c}}\end{array}$ & $\begin{array}{c}\cdot \\
\cdot \\
1,5 \\
0,3 \\
0,2 \\
0,2 \\
0,4 \\
0,4^{\mathrm{c}} \\
\end{array}$ & $\begin{array}{c}\cdot \\
46,9 \\
45,2 \\
37,9 \\
37,9 \\
31,6 \\
33,6^{c}\end{array}$ & $\begin{array}{c}\cdot \\
24,2 \\
23,9 \\
27,4 \\
31,1 \\
34,6 \\
29,8^{\mathrm{c}}\end{array}$ & $\begin{array}{c}\cdot \\
28,6 \\
30,3 \\
33,6 \\
30,7 \\
33,3 \\
35,9^{\text {c }}\end{array}$ & $\begin{array}{l}\cdot \\
0,3 \\
0,6 \\
1,5 \\
0,3 \\
0,5 \\
0,7^{\mathrm{c}}\end{array}$ \\
\hline Słowacja & $\begin{array}{l}2004 \\
2005 \\
2006 \\
2007 \\
2008 \\
2009 \\
2010 \\
2011 \\
\end{array}$ & $\begin{array}{l}49,2 \\
49,8 \\
43,1 \\
39,6 \\
42,9 \\
41,0 \\
42,1 \\
37,2 \\
\end{array}$ & $\begin{array}{l}20,1 \\
20,4 \\
24,1 \\
25,0 \\
24,3 \\
25,0 \\
27,6 \\
34,9 \\
\end{array}$ & $\begin{array}{l}30,5 \\
29,7 \\
32,8^{\mathrm{e}} \\
35,4^{\mathrm{e}} \\
32,8^{\mathrm{e}} \\
33,9^{\mathrm{e}} \\
30,0^{\mathrm{e}} \\
27,7^{\mathrm{e}}\end{array}$ & $\begin{array}{l}0,2 \\
0,1 \\
0,1 \\
0,1 \\
0,1 \\
0,0 \\
0,3 \\
0,2 \\
\end{array}$ & $\begin{array}{l}24,2 \\
24,5 \\
20,9 \\
17,5 \\
17,6 \\
16,5 \\
17,8 \\
18,0 \\
\end{array}$ & $\begin{array}{l}50,8 \\
49,7 \\
54,1 \\
55,1 \\
55,2 \\
58,8 \\
58,1 \\
59,3 \\
\end{array}$ & $\begin{array}{l}24,3^{\mathrm{e}} \\
25,8^{\mathrm{e}} \\
24,8^{\mathrm{e}} \\
27,3^{\mathrm{e}} \\
27,0^{\mathrm{e}} \\
24,9^{\mathrm{e}} \\
24,0^{\mathrm{e}} \\
22,7^{\mathrm{e}}\end{array}$ & $\begin{array}{l}0,7 \\
\mathrm{~g} \\
0,2 \\
0,1 \\
0,2 \\
- \\
0,1 \\
\mathrm{~g} \\
\end{array}$ \\
\hline Słowenia & $\begin{array}{l}2004 \\
2005 \\
2006 \\
2007 \\
2008 \\
2009 \\
2010 \\
2011\end{array}$ & $\begin{array}{c}\cdot \\
60,2 \\
59,8 \\
64,6^{\mathrm{c}} \\
64,6 \\
67,8 \\
73,9^{\mathrm{c}}\end{array}$ & $\begin{array}{c}\cdot \\
15,1 \\
15,6 \\
13,4^{\mathrm{c}} \\
14,6 \\
13,9 \\
11,8^{\mathrm{c}}\end{array}$ & $\begin{array}{c}\cdot \\
24,5 \\
24,5 \\
21,9^{\mathrm{c}} \\
20,8 \\
18,2 \\
14,3^{\mathrm{c}}\end{array}$ & $\begin{array}{l}\cdot \\
0,2 \\
0,1 \\
0,1^{\mathrm{c}} \\
0,1 \\
0,1 \\
0,1^{\mathrm{c}}\end{array}$ & $\begin{array}{c}\cdot \\
49,1 \\
51,1 \\
53,5^{\mathrm{c}} \\
54,7 \\
54,5 \\
63,0^{\mathrm{c}}\end{array}$ & $\begin{array}{c}\cdot \\
21,6 \\
18,8 \\
18,2^{\mathrm{c}} \\
19,0 \\
21,1 \\
19,7^{\mathrm{c}}\end{array}$ & $\begin{array}{c}\cdot \\
29,0 \\
29,9 \\
28,1^{\mathrm{c}} \\
26,2 \\
24,3 \\
17,2^{\mathrm{c}}\end{array}$ & $\begin{array}{l}\cdot \\
0,3 \\
0,2 \\
0,2^{\mathrm{c}} \\
0,1 \\
0,1 \\
0,1^{\mathrm{c}}\end{array}$ \\
\hline Szwecja & $\begin{array}{l}2004 \\
2005 \\
2006 \\
2007 \\
2008 \\
2009 \\
2010 \\
2011\end{array}$ & $\begin{array}{l}73,5 \\
74,1 \\
74,7 \\
72,7 \\
74,1^{b} \\
70,4 \\
68,7^{\mathrm{b}} \\
69,3^{\mathrm{b}, \mathrm{c}}\end{array}$ & $\begin{array}{l}22,9 \\
20,9 \\
20,6^{\mathrm{b}} \\
22,2^{\mathrm{b}} \\
21,3^{\mathrm{b}} \\
25,1 \\
26,3^{\mathrm{b}} \\
26,0^{\mathrm{b}, \mathrm{c}}\end{array}$ & $\begin{array}{l}3,1 \\
4,7 \\
4,5^{\mathrm{b}} \\
5,0 \\
4,4^{\mathrm{b}} \\
4,4 \\
4,9^{\mathrm{b}} \\
4,3^{\mathrm{b}, \mathrm{c}}\end{array}$ & $\begin{array}{l}0,4 \\
0,3 \\
0,2^{\mathrm{b}} \\
0,2^{\mathrm{c}} \\
0,2^{\mathrm{b}} \\
0,1^{\mathrm{c}, \mathrm{h}} \\
0,0^{\mathrm{b}, \mathrm{h}} \\
0,3^{\mathrm{b}, \mathrm{c}}\end{array}$ & $\begin{array}{l}65,0 \\
72,2^{\mathrm{c}} \\
73,2^{\mathrm{c}} \\
72,0^{\mathrm{c}, \mathrm{i}} \\
73,9^{\mathrm{b}} \\
71,6^{\mathrm{i}} \\
70,8^{\mathrm{b}, \mathrm{i}} \\
69,8^{\mathrm{b}, \mathrm{c}}\end{array}$ & $\begin{array}{l}30,2 \\
22,8^{\mathrm{c}} \\
21,8 \\
23,6 \\
22,1^{\mathrm{b}} \\
24,9 \\
25,2 \\
25,6^{\mathrm{b}}\end{array}$ & $\begin{array}{l}4,2 \\
4,6^{\mathrm{c}} \\
4,6 \\
4,4 \\
3,7^{\mathrm{b}} \\
3,4^{\mathrm{i}} \\
4,0^{\mathrm{b}, \mathrm{h}} \\
4,3^{\mathrm{c}, \mathrm{d}}\end{array}$ & $\begin{array}{l}0,6 \\
0,4^{\mathrm{c}} \\
0,4 \\
\mathrm{~g} \\
0,3^{\mathrm{b}} \\
0,1 \\
\mathrm{~g} \\
0,3\end{array}$ \\
\hline
\end{tabular}




\begin{tabular}{||c|c|c|c|c|c|c|c|c|c||}
\hline \hline 1 & 2 & 3 & 4 & 5 & 6 & 7 & 8 & 9 & 10 \\
\hline Węgry & 2004 & 41,1 & 24,6 & 29,5 &. & 29,4 & 37,4 & 33,3 &. $\mathrm{~g}$ \\
& 2005 & 43,2 & 25,1 & 28,0 &. & 31,8 & 35,2 & 32,9 & 0,1 \\
& 2006 & 48,3 & 24,4 & 25,4 &. & 35,7 & 32,8 & 31,4 & 0,1 \\
& 2007 & 50,3 & 23,3 & 24,2 &. & 39,8 & 29,9 & 30,1 & 0,2 \\
& 2008 & 52,6 & 22,0 & 23,4 &. & 41,5 & 29,1 & 29,4 & .9 \\
& 2009 & 57,2 & 20,9 & 20,1 &. & 44,3 & 28,1 & 27,7 & .9 \\
& 2010 & 59,8 & 19,9 & 18,5 &. & 47,6 & 26,2 & 26,1 & 0,1 \\
& 2011 & 62,4 & 20,2 & 15,8 &. & 50,7 & 24,3 & 25,0 & .9 \\
\hline Wielka & 2004 & 62,6 & 24,7 & 10,7 & 2,0 & $47,7^{\mathrm{j}}$ &. & $6,6^{\mathrm{j}}$ &. \\
Brytania & 2005 & 61,4 & 25,7 & 10,6 & 2,3 & $45,2^{\mathrm{j}}$ &. & $6,3^{\mathrm{j}}$ &. \\
& 2006 & 61,7 & 26,1 & 10,0 & 2,2 & $44,6^{\mathrm{b}, \mathrm{i}}$ & 47,2 & 6,1 & 2,1 \\
& 2007 & 62,5 & 26,1 & 9,2 & 2,2 & $45,8^{\mathrm{b}, \mathrm{i}}$ & 47,0 & 5,4 & 1,8 \\
& 2008 & $62,0^{\mathrm{b}}$ & $26,5^{\mathrm{b}}$ & $9,2^{\mathrm{b}}$ & $2,4^{\mathrm{b}}$ & $44,5^{\mathrm{b}, \mathrm{i}}$ & 47,8 & 5,4 & 2,3 \\
& 2009 & $60,4^{\mathrm{b}}$ & $27,9^{\mathrm{b}}$ & $9,2^{\mathrm{b}}$ & $2,5^{\mathrm{b}}$ & $43,6^{\mathrm{b}, \mathrm{i}}$ & 48,6 & 5,4 & 2,4 \\
& 2010 & $60,9^{\mathrm{b}}$ & $27,0^{\mathrm{b}}$ & $9,5^{\mathrm{b}}$ & $2,5^{\mathrm{b}}$ & $44,2^{\mathrm{b}, \mathrm{i}}$ & 48,7 & 5,4 & 1,7 \\
& 2011 & $61,5^{\mathrm{d}}$ & $26,9^{\mathrm{d}}$ & $9,3^{\mathrm{d}}$ & $2,4^{\mathrm{d}}$ & $44,2^{\mathrm{d}}$ & $48,6^{\mathrm{d}}$ & $5,3^{\mathrm{d}}$ & $1,9^{\mathrm{d}}$ \\
\hline Włochy & 2004 & 47,8 & 32,8 & 17,8 & 1,5 & 41,2 & 37,0 & 19,8 & 2,0 \\
& 2005 & 50,4 & 30,2 & 17,3 & 2,1 & 40,4 & $38,3^{\mathrm{c}}$ & 18,7 & 2,6 \\
& 2006 & 48,8 & 30,3 & 17,2 & 3,7 & 41,7 & 35,2 & 18,8 & 4,3 \\
& 2007 & 51,9 & 30,1 & 14,5 & 3,5 & 45,0 & 34,1 & 17,0 & 3,9 \\
& 2008 & 53,6 & 30,5 & 12,7 & 3,2 & 48,2 & 32,8 & 15,4 & 3,6 \\
& 2009 & 53,3 & 30,3 & 13,1 & 3,3 & 48,5 & 33,1 & 14,9 & 13,5 \\
& 2010 & 53,9 & 28,8 & 13,7 & 3,6 & 49,7 & 32,0 & 15,4 & 2,9 \\
& 2011 & $54,2^{\mathrm{d}}$ & $28,6^{\mathrm{d}}$ & $13,7^{\mathrm{d}}$ & $3,5^{\mathrm{d}}$ & $50,3^{\mathrm{d}}$ & $31,8^{\mathrm{d}}$ & $15,1^{\mathrm{d}}$ & $2,8^{\mathrm{d}}$ \\
\hline \hline
\end{tabular}

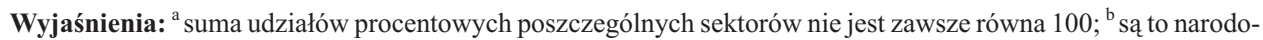
we szacunki albo prognozy; ${ }^{c}$ informacje nie w pełni porównywalne $\mathrm{z}$ danymi statystycznymi za poprzednie lata; ${ }^{\mathrm{d}}$ dane prowizoryczne; ${ }^{\mathrm{e}}$ wyłączone są w pełni albo w przeważającej mierze prace i badawcze i rozwojowe o charakterze militarnym; ${ }^{\mathrm{f}}$ obejmuje także inne sektory; ${ }^{\mathrm{g}}$ dane zawarte w innych sektorach; ${ }^{\mathrm{h}}$ dane zaniżone; ${ }^{\mathrm{i}}$ dane zawyżone; ${ }^{j}$ szacunki Sekretariatu OECD albo prognozy oparte na źródłach narodowych.

Źródla: OECD (2008), Main and Science and Technology Indicators, vol. 2008/2, Paris 2008, s. 26, 27, 32, 33, 43 i 44; OECD (2013), Main and Science and Technology Indicators, vol. 2013/1, Paris 2013, s. 36-39, 49, 50, 70 i 77; obliczenia własne.

\section{Reformy nauki polskiej}

Słaba pozycja nauki polskiej, w tym wśród krajów unijnych skłaniała do podejmowania jej reform. Reformy te były przeprowadzane w okresie pełnienia funkcji ministra nauki i szkolnictwa wyższego przez prof. B. Kudrycką. Na podstawie ustaw z 30 kwietnia 2010 r., (Dz. U. 2010, Nr 96, poz. 616 i 617) dokonano podziału kompetencji w zakresie popierania $\mathrm{B}+\mathrm{R}$ między dwie agencje, a mianowicie między Narodowe Centrum Badań i Rozwoju (NCBR) oraz Narodowe Centrum Nauki (NCN). Pierwsze powstało już w 2007 r., a drugie - w październiku 2010 r. Stosownie do przyjętych uregulowań główne zadanie NCBR polega na zarządzaniu strategicznymi programami badań naukowych (badań stosowanych) i prac rozwojowych oraz na współfinansowaniu lub finansowaniu tych programów. Zasadnicza funkcja NCN przejawia się natomiast w ponoszeniu kosztów badań podstawowych. Dokonanie tego podziału kompetencji miało przyczynić się do właściwego wyboru w konkursie wspieranych projektów.

Trafnym rozwiązaniem było również postanowienie o systematycznym wzroście do 2020 r. udziału wydatków na działalność NCBR i NCN do 50\% (pozostałych) fun- 
duszy przekazywanych przez Ministerstwo Nauki i Szkolnictwa Wyższego na naukę. Wzrost ten następowałby kosztem środków na badania statutowe, otrzymywanych automatycznie.

Na razie granty z NCN w niewystarczającym stopniu promują naukowców. Otrzymują oni miesięcznie dodatkowo co najwyżej 500 zł (Krysztofiak, s. 2 i 3).

W myśl ustawy z 30 IV 2010 r. o instytutach badawczych instytuty te powstały z jednostek badawczo-rozwojowych, które uzyskały kategorię 1, 2, 3, 4 lub 5. Rozumiano przez instytuty badawcze państwowe jednostki organizacyjne, wyodrębnione pod względem prawnym, organizacyjnym i ekonomiczno-finansowym, prowadzące badania naukowe i prace rozwojowe ukierunkowane na ich wdrożenie i zastosowanie w praktyce (Instytut badawczy, s. 1).

Przekształcenie to miało na celu zwiększenie efektywności B+R, gdyż instytuty wykazują szereg różnic w porównaniu z jednostkami badawczo-rozwojowymi. I tak w ustawie wprowadzono obowiazzek przeprowadzenia raz na 4 lata kompleksowej oceny działalności naukowej i badawczo-rozwojowej (art. 34 ust. 1 i 2). Wzmocniono nadzór kompetentnego ministra nad funkcjonowaniem instytutu badawczego poprzez zastosowanie audytów dokonywanych co 3 lata i obejmujących całokształt działalności (art. 36 ust. 1 i 2). Przewidziano również możliwość współpracy naukowo-gospodarczej instytutów w ramach centrów naukowo-przemysłowych. W centrach mogą uczestniczyć również uczelnie i instytuty naukowe Polskiej Akademii Nauk oraz zagraniczne instytuty naukowe, a współdziałanie - dokonywać się powinno w formie klastrów, parków technologicznych, platform technologicznych itd. (art. 38 ust. 1, 2 i 7). Zadania centrów byłyby zbliżone do centrów PAN. Stworzenie tych ostatnich instytucji naukowych przewidywał art. 57 ustawy o Polskiej Akademii Nauk. Tworzenie centrów, w których będą współpracować instytuty PAN, należałoby do zadań Prezydium Akademii i następowałoby na wniosek Prezesa Akademii (art. 57 ust. 1). Uczestniczyć mogły także uczelnie, instytuty badawcze, przedsiębiorcy prowadzący B+R oraz zagraniczne instytucje (art. 57 ust. 1 i 2). Do zadań centrów należałoby: wspieranie i koordynacja działalności badawczej instytutów, inicjowanie i koordynowanie udziału instytutów, uczelni i innych jednostek naukowych w międzynarodowych programach badawczych, inicjowanie organizowania środowiskowych centrów aparaturowych oraz nadzór nad nimi. Dalsze zadania to współdziałanie w organizowaniu środowiskowych studiów doktoranckich, organizowanie wymiany pracowników pomiędzy instytutami a uczelniami, rozwijanie programów staży dla osób z ukończonym doktoratem w instytutach PAN należących do centrum, pozyskiwanie i obsługa projektów badawczych międzynarodowych, wspólnych projektów badawczych krajowych i finansowanych z funduszy europejskich (art. 57, ust. 6, z. 1-6).

Zmierzając do zwiększenia efektywności pracowników naukowych Minister Nauki i Szkolnictwa Wyższego wydał w lipcu 2012 r. rozporządzenie w sprawie kryteriów i trybu przyznawania kategorii naukowej jednostkom naukowym. Otrzymuje się ją za okres 4 kolejnych lat kalendarzowych działalności jednostki poprzedzających rok złożenia wniosku o kategoryzację $(\S 2$, z. 4$)$. W grę wchodzą przy tym cztery następujące kategorie: A+ (poziom wiodący w skali kraju), A (poziom bardzo dobry), B (poziom akceptowalny z rekomendacją wzmocnienia działalności naukowej) i C (poziom niezadawalający). W myśl postanowień rozporządzenia organ dokonujący oceny (Ko- 
mitet Ewaluacji Jednostek Naukowych) stosuje cztery rodzaje kryteriów. Są to w szczególności osiagnięcia naukowe i twórcze, ale i także potencjał naukowy, materialne efekty działalności naukowej i pozostałe efekty działalności naukowej (§ 6). Podstawą dla określenia osiagnięć naukowych i twórczych jest ogłaszany przez Ministra nie rzadziej niż raz w roku wykaz czasopism naukowych wraz z liczbą punktów przyznawanych za publikację w tych czasopismach $(\S 14$, z. 2$)$.

Dokonanie oceny dorobku publikacyjnego pracowników naukowych jest rzeczą niezbędna, nie można tu jednak nie zwrócić uwagi na pewne mankamenty przyjętego w Polsce systemu. O liczbie przypisanych czasopismom punktów decyduje swobodna ocena, a czasopisma zagraniczne (a zwłaszcza anglojęzyczne) otrzymują dużo więcej punktów niż krajowe (Brandt, 2011, s. 137). Z kolei umieszczenie artykułu w mniej punktowanym czasopiśmie krajowym nie musi oznaczać, że reprezentuje on niższy poziom.

Wprawdzie na świecie ma miejsce tendencja do inflacji konferencji, pewnym nieporozumieniem jest zaliczanie do osiagnięć naukowych i twórczych jedynie publikacji $\mathrm{w}$ recenzowanych materiałach $\mathrm{z}$ konferencji międzynarodowych uwzględnionych $\mathrm{w}$,Web of Science”. Również na innych konferencjach międzynarodowych czy krajowych mogą być prezentowane ważne wyniki $\mathrm{B}+\mathrm{R}$.

W 2011 r. podjęto działania zmierzające do ograniczenia wieloetatowości, zaostrzając warunki dodatkowego zatrudnienia w uczelniach wyższych. W myśl art. 112a ustawy o szkolnictwie wyższym nauczyciel akademicki składa w uczelni oświadczenie o podstawowym miejscu pracy. Może dodatkowo złożyć w kolejnej jednostce organizacyjnej uczelni, w której pracuje albo jednostce organizacyjnej innej uczelni co najwyżej jedno oświadczenie, upoważniające tę jednostkę do zaliczenia go do minimum kadrowego jednego kierunku studiów pierwszego stopnia. Obydwa te oświadczenia muszą być złożone przed rozpoczęciem roku akademickiego, nie później jednak niż do dnia 30 czerwca roku poprzedzającego rok akademicki.

Jak wynika z kolei z art. 129 ustawy o szkolnictwie wyższym, nauczyciel akademicki zatrudniony w uczelni publicznej musi uzyskać zgodę na dodatkowe zatrudnienie u pracodawcy prowadzącego działalność dydaktyczną lub naukowo-badawczą rektora uczelni. Rektor może odmówić wyrażenia zgody, jeśli wykonanie dodatkowej pracy wpłynie negatywnie na funkcjonowanie uczelni lub będzie związane $\mathrm{z}$ wykorzystaniem jej urządzeń technicznych i zasobów.

W przypadku instytutów naukowych PAN i instytutów badawczych zaostrzenie polegało na wprowadzeniu obowiązku uzyskania zgody dyrektora instytutu i obowiązywało od października $2010 \mathrm{r}$. Podstawy do jego wprowadzenia stanowily art. 47 ust. 1 ustawy o instytutach badawczych oraz art. 94 ust. 3 ustawy o Polskiej Akademii Nauk.

Podniesieniu poziomu prac badawczych i rozwojowych miała służyć również przeprowadzona w 2011 r. reforma habilitacji. Ustawą z 18 marca 2011 r., obowiązującą od 1 października tegoż roku zniesiono kolokwium habilitacyjne, a zadanie oceny dorobku habilitanta powierzono siedmioosobowej komisji (art. 2). Wydaje się, że przyjęte rozwiązanie jest dyskusyjne. Oceny poziomu naukowego kandydata dokonuje się tu bowiem jedynie na podstawie jego prac naukowych, pomija się ogólną wiedzę z danej dziedziny.

Rozporządzeniem Ministra Nauki i Szkolnictwa Wyższego z 1 września 2011 r. (art. 2) określono precyzyjnie dorobek naukowy stanowiący podstawę do oceny dzia- 
łalności naukowej hablitanta. Dorobek ten musi stanowić znaczący wkład do rozwoju nauki, a składają się nań w szczególności publikacje naukowe prezentowane w czasopismach uwzględnianych w bazach JCR, ERIH i WOS, jak i też patenty. W dalszej mierze będą to: kierowanie projektami badawczymi, nagrody za osiagnięcia naukowe oraz referaty na konferencjach międzynarodowych (§ 3-5).

\section{Zakończenie}

Z przeprowadzonych rozważań wynika, że relatywna pozycja Polski w zakresie $\mathrm{B}+\mathrm{R}$ była w analizowanym okresie (2004-2011) w UE bardzo słaba. Wskazywały na to dane statystyczne dotyczące liczby publikacji na $1 \mathrm{mln}$ mieszkańców, cytowań na 1 publikację oraz przypadających na 1 mln mieszkańców patentów triady, patentów w sektorze ITC i biotechnologii. Polska ustępowała tu nie tylko starym państwom członkowskim, ale również większości nowych członków.

Podstawowymi przyczynami, które zaważyły na bardzo słabej pozycji Polski w zakresie $\mathrm{B}+\mathrm{R}$, były niska intensywność badawczo-rozwojowa i zbyt mały udział firm w finansowaniu B+R. Dalsze uwarunkowania to wąski zakres współpracy między przedsiębiorstwami a uczelniami wyższymi, zbyt małe uczestnictwo strony polskiej w ramowych programach badań, rozwoju technologicznego i demonstracji, jak i też praca pracowników naukowych na wielu etatach.

Pod wpływem bardzo słabej pozycji nauki polskiej, w tym także w UE, podjęto w okresie kadencji minister B. Kudryckiej rozległe reformy. Dotyczyły one kompetencji w zakresie popierania przez państwo $B+R$, organizacji nauki, kategoryzacji jednostek naukowych, walki z wieloetatowością oraz przeobrażeń w procedurze habilitacyjnej. Przyjęte nowe rozwiązania mogą przyczynić się tylko do pewnego wzrostu pozycji Polski w zakresie B+R w Unii. Istotne wzmocnienie tej pozycji nastapi jedynie, gdy firmy polskie zmienią swój stosunek do popierania prac badawczych i rozwojowych.

\section{Bibliografia}

Brandt A. M. (2011), O parametryzacji ocen w nauce w Polsce, „Nauka”, nr 3.

Budziński F. (1972), Rola postęu naukowo-technicznego w rozwoju gospodarczym, Zakład Narodowy im. Ossolińskich, Wydawnictwo Polskiej Akademii Nauk, Wrocław-Warszawa-Kraków-Gdańsk.

Cowen T., Public Goods and Externalities, Http://www.econlib.org.

European Commission, Key Figures 2007. Towards a European Research Area. Science, Technology and Innovation.

Europe in figures - Eurostat yearbook... (różne roczniki).

Główny Urząd Statystyczny, Urząd Statystyczny w Szczecinie (2013), Nauka i technika w 2012 r. Informacje i Opracowania Statystyczne, Warszawa.

Gorynia-Pfeffer N. (2012), Institutionelle Rahmenbedingungen des nationalen Innovationssystems in Deutschland und Polen - Implikationen für Polen, Dissertation verfasst unter wissenschaftlicher Betreuung von Prof. Dr. habil. A. Budnikowski, Warsaw School of Economics, Collegium of World Economy, Warschau. 
http://www.scimagojr.com/countryrank.

Instytut badawczy, pl.wikipedia.org/wiki.

Klodt H. (1995), Grundlagen der Forschungs- und Technologiepolitik, Verlag Franz Vahlen, München.

Krysztofiak W., Kto zostanie ministrem nauki po Kudryckiej? Prof.Lena Kolarska-Bobińska? Czy Kluzik-Rostkowska?, http://blogi.newsweek.pl.

OECD, Main and Science and Technology Indicators (różne półroczniki).

OECD (2002), Podręcznik Frascati. Proponowane procedury standardowe dla badań statystycznych $w$ zakresie działalności badawczo-rozwojowej.

Öffentliches Gut, http://de.wikipedia.org.

Orłowska J., Mikroprzedsiębiorstwa w Polsce, czyli o większości polskich firm, „Biuletyn Euro Info”, http://www.een.org.pol, s. 1.

pl.wikipedia.org/wiki/Bułgaria.

pl.wikipedia.org/wiki/Cyprus.

pl.wikipedia.org/wiki/Litwa.

Prezentacja form wspólpracy między uczelniami wyższymi a światem biznesu, www.skillsforthefuture.iped.pl.

Rozporządzenie Ministra Nauki i Szkolnictwa Wyższego z dnia 1 września 2011 r. w sprawie kryteriów oceny osiagnięć ubiegajacej się o nadanie stopnia doktora habilitacyjnego, Dz. U. 2011, Nr 196, poz. 1165.

Rozporządzenie Ministra Nauki i Szkolnictwa Wyższego z dnia 13 lipca 2012 r. w sprawie kryteriów i trybu przyznawania kategorii naukowej jednostkom naukowym, Dz. U. 2012, Nr 0, poz. 877.

Uczelnie zaczynaja wspótpracować z firmami, http://praca.gazetaprawna.pl./artykuły, s. 1.

Ustawa z 27 VII 2005 r. Prawo o szkolnictwie wyższym, Dz. U. 2005, Nr 164, poz. 1365.

Ustawa z 30 IV 2010 r. o Narodowym Centrum Badań i Rozwoju, Dz. U. 2010, Nr 96, poz. 616.

Ustawa z 30 IV 2010 r. o Narodowym Centrum Nauki, Dz. U. 2010, Nr 96, poz. 617.

Ustawa z 30 IV 2010 r. o instytutach badawczych, Dz. U. 2010, Nr 96, poz. 618.

Ustawa z 30 IV 2010 r. o Polskiej Akademii Nauk, Dz. U. 2010, Nr 96, poz. 619.

Ustawa z 27 VII 2005 r. Prawo o szkolnictwie wyższym, Dz. U. 2005, Nr 164, poz. 1365, z późn. zm.

Ustawa z 18 III 2011 r. o zmianie ustawy - Prawo o szkolnictwie wyższym, ustawy o stopniach naukowych i tytule naukowym oraz o stopniach i tytule w zakresie sztuki oraz o zmianach niektórych innych ustaw, Dz. U. 2011, Nr 84, poz. 455.

Wilkin J. (2013), Finansowanie nauki i szkolnictwa wyższego w Polsce. Wybrane problemy i postulowane kierunki reform, „Studia BAS”, nr 3, s. 51-70.

\section{Streszczenie}

Przedmiotem analizy jest w artykule (relatywna) pozycja Polski w zakresie prac badawczych i rozwojowych w Unii Europejskiej. Autor wykazuje, że ta pozycja jest bardzo słaba, czego przyczyny tkwią zwłaszcza w niskiej intensywności badawczo-rozwojowej oraz zbyt małym zaangażowaniu firm w finansowanie $B+R$. Dalsze uwarunkowania to zbyt wąska współpraca między firmami, zbyt małe zaangażowanie polskich instytucji naukowych w realizację unijnego programu ramowego w dziedzinie badań i rozwoju technologicznego, jak i wieloetatowość. 
Autor podkreśla, że pod wpływem bardzo słabej pozycji w sferze B+R nastąpiły w Polsce poważne reformy. Nie wzmocnią one jednak w sposób istotny tej pozycji, gdyż zależy ona od zmiany stosunku firm do popierania $\mathrm{B}+\mathrm{R}$.

Slowa kluczowe: $B+R$, badania naukowe w UE

\section{Position of Poland in the area of research and development in the European Union}

\section{Summary}

The author analyses Poland's (relative) research and development position among EU member countries. He indicates that Poland is among EU countries making very slow scientific progress which is caused, first and foremost, by low R\&D intensity and limited involvement of businesses in financing R\&D. The limited scope of scientific cooperation between businesses and universities, the insufficient participation of Polish scientific institutions in the EU Framework Programme for Research, technological development and demonstration activities, as well as multiple employment (of scientists and researchers) are other reasons.

Given Poland's extremely weak position in the area of R\&D, extensive reforms have been made. They will not significantly strengthen Poland's R\&D status, however, because this depends on the attitude of businesses to supporting R\&D.

Key words: $R \& D$, research in the EU 
